
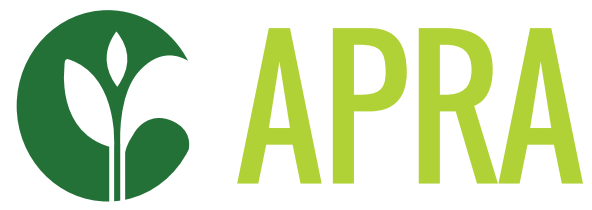

Agricultural Policy Research in Africa

\title{
LIVESTOCK, CROP COMMERCIALISATION AND POVERTY REDUCTION AMONG RURAL HOUSEHOLDS IN THE SINGIDA REGION, TANZANIA
}

Ntengua S.Y. Mdoe, Gilead I. Mlay, Gideon Boniface, Aida. C. Isinika and Christopher Magomba 


\section{TABLE OF CONTENTS}

Acknowledgements................................................................................................... 4

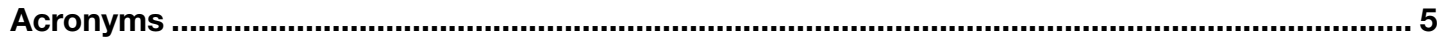

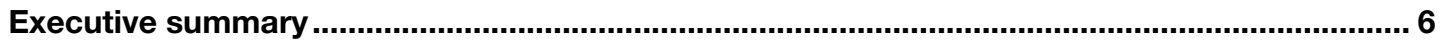

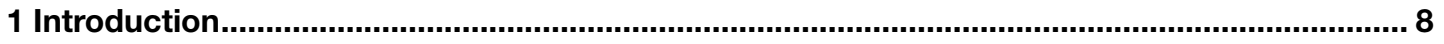

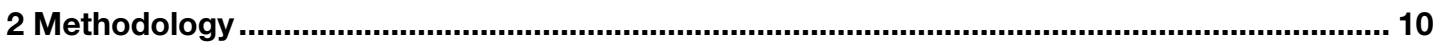

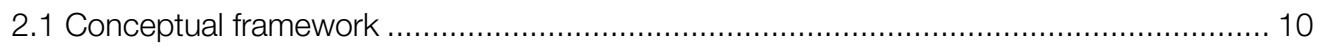

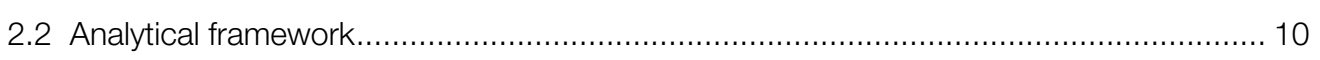

2.2.1 Determining the effect of livestock on crop commercialisation....................... 10

2.2.2 Determining the effect of livestock and other factors on poverty among rural

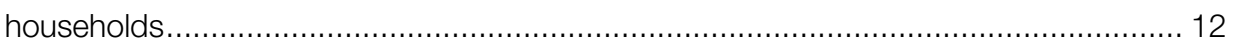

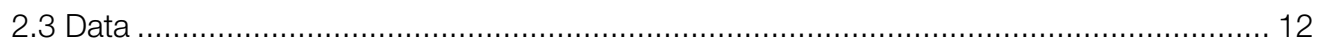

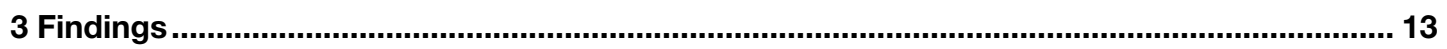

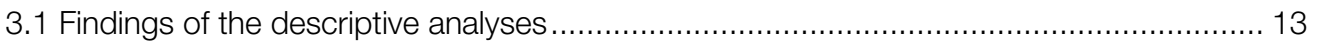

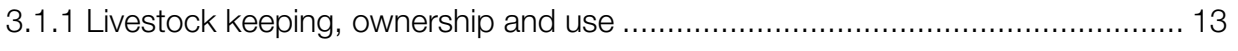

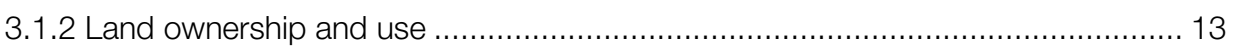

3.1.3 Ownership of other productive assets ......................................... 14

3.1.4 Use of modern tillage implements and productivity enhancing inputs and

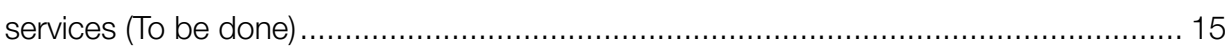

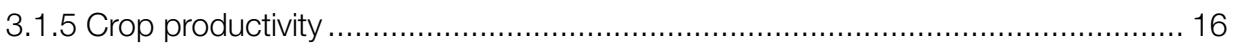

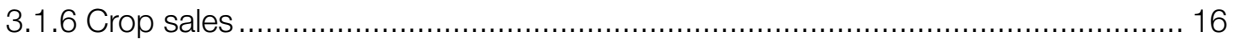

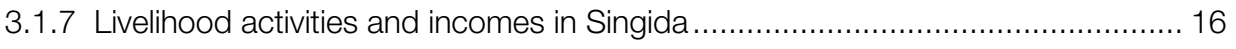

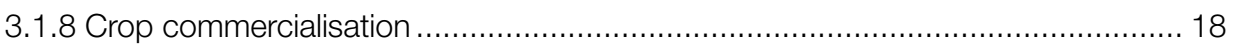

3.1.9 Household income, food security and poverty across different categories

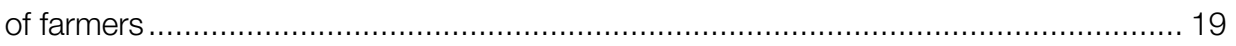

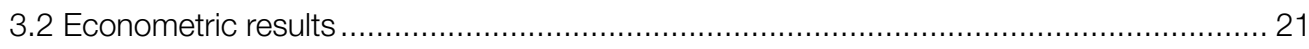

3.2.1 The effect of livestock on crop commercialisation: Results of the fractional

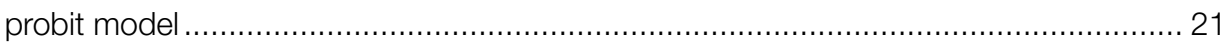

3.2.2 The effect of livestock on household poverty: Results of the probit model.......... 23

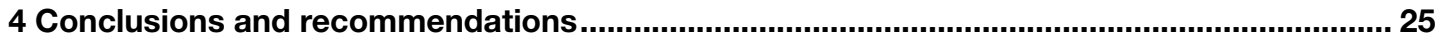

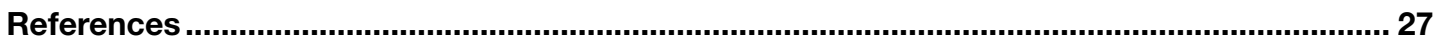

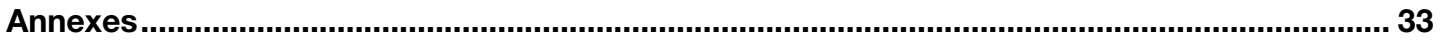

Annex 1: Specification of explanatory variables used in the fractional probit model for

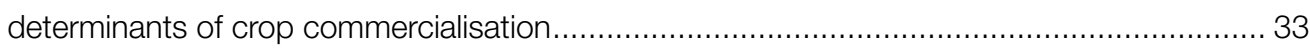

Annex 2: Indicators used to compute the Multi Poverty Index (MPI) ............................. 34

Annex 3: List of food insecurity situations used to classify households into food secure and 
food insecure households (HFSS) 34

Annex 4: List of explanatory variables for estimating the probit model for MPI................... 35

Annex 5: Map of the Singida region and Iramba and Mkalama districts......................... 36

\section{List of figures}

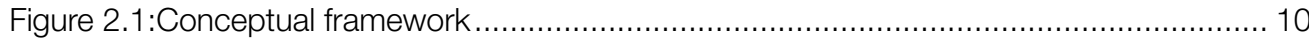

Figure 3.1: Total income portfolios for the whole sample ........................................... 18

\section{List of tables}

Table 3.1: Ownership of livestock/birds by farmer category...... 13

Table 3.2: Land owned per household (ha) by farmer category.

Table 3.3: Mean land area allocated to different crops per household (ha) by farmer category in 2017/18 farming season.

Table 3.4: Percentage of households owning different productive assets by farmer category

Table 3.5: Percentage of households using modern tillage implements and productivity enhancing inputs and services.

Table 3.6: Crop yields (kg/ha) for major crops grown in 2017/18 farming season by farmer category

Table 3.7: Crop sales (kg per households) for major crops sold in 2017/18 farming season

by farmer category

Table 3.8: Average cultivated land area under crop production and percentage of households growing the crop

Table 3.9: Average number of livestock and percentage of households keeping th livestock 17

Table 3.10: Distribution of sample households by type of non-farm income activity 17

Table 3.11: Pattern of income portfolios (Percentage of total income) by farmer category...... 18

Table 3.12: Mean commercialisation indices (per cent) for major crops grown in the 2017/18 farming season by farmer category

Table 3.13: Overall crop commercialisation indices (per cent) by farmer category..... 19

Table 3.14: Percentage of households by income source and famer category, 2017/18....... 20

Table 3.15: Percentage of households that are food-secure and insecure by farmer category

Table 3.16: Percentage of households by poverty level (MPI) and farmer category

Table 3.17: Determinants of crop commercialisation in Singida Region: results of the fractional probit regression $(\mathrm{CCl} \leq 1)$ 23

Table 3.18: Determinants of household poverty status: probit estimates 24 


\section{ACKNOWLEDGEMENTS}

Funding for this research is provided by Agricultural Policy Research in Africa; a five-year research programme consortium funded by the Foreign, Commonwealth \& Development Office (FCDO). The programme, which is based at the Institute of Development Studies (IDS) (www.ids.ac.uk), builds on more than a decade of research and policy engagement work by the Future Agricultures Consortium (www.future-agricultures.org). We are very grateful to all the farmers and key informants in the Iramba and Mkalama districts of the Singida region, who willingly spared their time to respond to the long questionnaire. The research team also appreciates the work done by the enumerators who interviewed the farmers.

Ntengua Mdoe and Gilead Mlay are retired professors, and Christopher Magomba is a lecturer from the School of Agricultural Economics and Business Studies, Sokoine University of Agriculture (SUA). Aida Isinika is a retired professor at the Institute of Continuing Education, SUA. Gideon Boniface is an independent researcher based in Morogoro, Tanzania.

This working paper is funded with UK aid from the UK government (Foreign, Commonwealth \& Development Office - FCDO, formerly DFID). The opinions are the authors and do not necessarily reflect the views or policies of IDS or the UK government. 


\section{ACRONYMS}

$\begin{array}{ll}\text { APRA } & \text { Agricultural Policy Research for Africa } \\ \text { CCI } & \text { Crop Commercialisation Index } \\ \text { FHH } & \text { female-headed household } \\ \text { MHH } & \text { male-headed household } \\ \text { MPI } & \text { Multidimensional Poverty Index } \\ \text { MSF } & \text { medium-scale farmer } \\ \text { SSA } & \text { sub-Saharan Africa } \\ \text { SSF } & \text { small-scale farmer } \\ \text { TANROADS } & \text { Tanzania National Roads Agency } \\ \text { TARURA } & \text { Tanzania Rural and Urban Roads Agency } \\ \text { TLU } & \text { Tropical Livestock Unit }\end{array}$




\section{EXECUTIVE SUMMARY}

Livestock is an important component of mixed croplivestock farming systems in the Singida Region in Tanzania, directly or indirectly contributing to household income, food security and poverty reduction among rural people in the region. This paper examined the effect of livestock on crop commercialisation and farmers' livelihoods in the region. It was expected that livestock would enhance crop commercialisation as measured in terms of the Crop Commercialisation Index (CCl) and improve livelihoods among rural people in the region. The $\mathrm{CCl}$ was computed as a percentage of the gross value of major crops marketed out of the gross value produced. The crops used in the computation of $\mathrm{CCl}$ were maize, sunflower, rice, common bean, sorghum, pearl millet and groundnuts. Quantitative data for the analysis were extracted from the Agricultural Policy Research for Africa (APRA) data set of 600 households selected randomly from random samples of eight and seven villages in Iramba and Mkalama districts respectively. The quantitative data were complimented with qualitative data collected through focus group discussions and key informant interviews. Descriptive statistics were used to compare commercialisation levels and poverty levels across different categories of farmers. Regression analyses were used to determine if livestock had a significant effect on crop commercialisation and poverty levels, controlling for other variables that might have an effect.

The results of this study show that livestock enhanced crop commercialisation rather than inhibiting it. This enhancement stems from the provision of livestock manure for soil fertility improvement and animal traction as a tillage technology. The complementarity between crops and livestock in the farming systems of Singida needs to be recognised, enhanced and utilised not only by farmers and livestock keepers, but also by local government authorities and development practitioners. Apart from livestock, a range of other factors have worked together with livestock to drive the crop commercialisation process. These factors include the use of tractors as a tillage implement, total land planted with crops, farmer's education level, distance to the nearest motorable road as a proxy for access to markets and use of productivity (yield) enhancing inputs such as improved seed, inorganic fertiliser and pesticides. However, the findings show that some factors are likely to be obstacles to crop commercialisation which, if addressed, can accelerate crop commercialisation processes. These factors include, but are not limited to, household size - which increases subsistence consumption at the expense of marketable surplus and poor access to crop markets due to absence of good roads linking crop producing villages to markets. Interventions to promote crop commercialisation should go hand in hand with efforts to increase access to family planning and reproductive health services in rural areas. Regarding market access, the government has made commendable improvements on major roads connecting regional and district headquarters in the country through the Tanzania National Roads Agency (TANROADS). However, much more needs to be done to improve and maintain roads connecting district headquarters to villages. This is the responsibility of the recently established Tanzania Rural and Urban Roads (TARURA) that needs to be implemented.

While commercialisation has been seen as a linear process whereby farming households specialise as they climb the ladder of commercialisation, evidence from our study shows that commercialisation has occurred in parallel with diversification within and outside the crop sub-sector. Reasons behind this tendency may include an aversion to risks that could arise from relying on a single enterprise desire to exploit a diversified demand for produce; and the importance for many small farmers of continuing to produce a large share of staples for home consumption. This calls for government and development partner efforts to promote enterprise diversity instead of the idea of 'one district, one crop', that remains in the books of extension service providers at the local government level, essentially promoting specialisation.

Regarding the impacts of commercialisation, the findings show that farmers have gained higher productivity (yield) and income levels from commercialised crops, signifying the potential of crop commercialisation to improve food security and reduce income poverty. The actual impact of commercialisation on food security and poverty depends on how the income is utilised. In general, evidence from the findings of our study show improvement in household food security and reduction in poverty as crop commercialisation increases from 
zero to medium level. However, household food security slightly declines and poverty level slightly increases as crop commercialisation increases from medium to high level. The decline in food security and increase in poverty can be associated with cultural factors among agropastoralists of keeping large numbers of livestock for prestige and dowry payment. Agropastoralists would rather sell harvested food crops to purchase livestock rather than sell livestock to purchase food and/or assets other than livestock.

Although crop commercialisation has positively impacted on crop productivity (yields), household incomes, food security and poverty, the results of our study show that some socio-economic disparities exist. Male-headed households $(\mathrm{MHH})$ and households headed by medium-scale farmers (MSF), young farmers and livestock keepers had significantly more income, were more food secure and less poor than their counterpart female-headed households $(\mathrm{FHH})$ and households headed by small-scale farmers (SSFs), old farmers and non-livestock keepers. These social differences are consequences of differential access to land, use of modern tillage implements and use of productivity enhancing inputs. In addition to more access to land, the use of modern tillage implements and productivity enhancing inputs was higher among $\mathrm{MHH}$ and households headed by MSF than $\mathrm{FHH}$ and households headed by SSF. Diversifying agriculture and livestock with non-farm incomes sources, particularly wage income from seasonal work and transfers, appears to be more important for the livelihoods of resource poor farmers (female and small-scale) than their counterparts (male and medium/large-scale). The mechanism of combining overlapping livelihood activities in the process of improving livelihoods of households in Singida needs to be recognised in efforts geared towards improving livelihoods and reducing social differentiation. Apart from efforts made by the government to improve access to land and financial resources from the local government fund for women and other vulnerable resource-poor people, deliberate efforts should be made to support non-farm income generating activities. 


\section{INTRODUCTION}

Livestock is an important component of mixed croplivestock farming systems in sub-Saharan Africa (SSA), providing food security and livelihood options for billions of rural people in the region (Jones and Thornton, 2009; Amejo and Habtemariam, 2018). Livestock's contribution to livelihoods can be seen directly through meat, milk and egg production which can be consumed by farming households to improve their food security and nutrition or sold to generate income. Livestock also contributes to livelihoods indirectly through the provision of farmyard manure and draft power for ploughing, weeding and transportation of farm produce. The extent of livestock's direct and indirect contribution to livelihoods depends on the type of mixed crop-livestock farming system, which can include mixed rainfed-arid-semi-arid, mixed rainfedhumid-sub-humid, mixed rainfed tropical highlands and mixed irrigated (Rust, 2018; Thornton and Herrero, 2015) and the degree of livestock-crop integration in the farming system (Sumberg, 2003). For example, in highly integrated systems, livestock provide draft power to cultivate the land and provide manure to fertilise the soil. At the same time, crop residues are a key feed resource for livestock.

The use of animal draft power and manures can enhance commercialisation of crops in the farming season by expanding land for crop production and increasing crop productivity respectively. However, as livestock numbers increase the competition for resources can inhibit commercialisation of crop production. Livestock production in the mixed crop-livestock farming system provides a new commercialisation pathway to crop farmers. Increasing the share of livestock income relative to that from crops would suppress the commercialisation tendency for crop-based income sources. Therefore, contrary to the expectation that livestock enhance crop commercialisation through the use of ox-plough and livestock manure, income generated from the sale of livestock and livestock products among crop farmers can have a negative effect on crop commercialisation by reducing the need to expand crop production. Apart from the potential effects of livestock on crop commercialisation, there are other factors that can enhance or inhibit the commercialisation process. These factors can be categorised into physical, technological, socio-economic, institutional and policy related factors (Pingali et al., 2019).

The aim of this study is to examine the effect of livestock on the agricultural commercialisation process in the Singida region in central Tanzania. The Singida region forms part of the semi-arid central zone of Tanzania, which experiences low rainfall and short and often erratic rain seasons, with fairly widespread drought every one in four years (Lema and Majule, 2009). Livestock are an integral component of the mixed crop-livestock farming systems in the region, comprising a wide range of crop and livestock enterprises. The crop enterprises include maize, millet, sorghum, paddy, cassava, sweet potatoes, sunflower, cotton, tobacco, wheat, beans, groundnuts, peas and onions while livestock enterprises include cattle, goats, sheep, donkeys and chickens. Besides the interaction between livestock and crop production activities, crop and livestock related activities have been interacting with other livelihood activities such as non-farm activities to create a wider scope of livelihood activities and pathways for rural households in the Singida region. The livelihood activities and choices among the rural households have been mediated by the local dynamics interacting with the broader national policy and business environment which have transformed agriculture from subsistence to commercial agriculture.

Agricultural commercialisation policies in SSA date back to the colonial period and have evolved differently during the colonial period, the post-colonial period, the structural adjustment period and the post-structural adjustment or liberalisation period. During the colonial period commercialisation efforts concentrated on the establishment of private estates and contract farming (Bates, 1981; Heyer, Roberts, and Williams, 1981) while in the post-colonial period, state-owned and-managed estates were promoted. During both periods, outgrower arrangements were promoted for cash crops such as cocoa, cotton, tobacco, sugarcane, coffee and tea as a means of integrating smallholder family farmers into commercial, and often transnational, value chains (Oya, 2011; Hall, Scoones and Tsikata, 2017). However, agricultural commercialisation interventions during the structural adjustment and in the poststructural adjustment periods in most SSA countries 
went beyond promotion of cash crops. The policies in the agricultural commercialisation process have been largely driven by exogenous (international and global) forces with very few of the countries in the region spearheading the process by local initiatives.

In general, agricultural commercialisation in SSA has been widely pursued to improve farm incomes, food security and the general welfare of farmers. However, the success of the commercialisation process in different countries across the region has varied, with some countries exhibiting far greater success than others. Besides the positive effects of agricultural commercialisation, it is important to bear in mind that agricultural commercialisation can also have negative or unintended impacts at household and community levels. For example, commercialisation has been criticised for its failure to improve household nutrition and livelihoods of the poor and reduce food security (Mutabazi, Wiggins and Mdoe, 2013; Zhou, Minde and Mtigwe, 2013; Gebremariam and Wünsher, 2016; Ogutu, Gödecke and Qaim, 2017). It has also been criticised for enhancing land degradation through the use of chemicals (Pingali, 2001), and being an expensive and risky undertaking process, especially among resource-poor farmers (Mutabazi, Wiggins and Mdoe, 2013). In general, the empirical evidence indicates that commercialisation affects socioeconomic groups differently (rich and poor, landowners and landless farmers, and women) under diverse biophysical, socioeconomic, institutional, and policy environments (Wallace and Moss, 2002; Fountas et al., 2006; Linderhof, Janssen and Achterbosch, 2019). The key underlying factors influencing the success and failure of the commercialisation process all point towards the need for strong public and private policies and initiatives to support improvised smallholder farmers in the agricultural commercialisation process as well. This calls for more empirical research in different geographical locations with diverse socioeconomic, institutional, and policy environments in order to inform policy to better support agricultural commercialisation.

While recognising that the success or failure of the agricultural commercialisation process cannot be attributed to any single factor but a combination of several factors complementing each other, this study examines the effect of livestock on crop commercialisation and how the commercialisation process has affected livelihoods of rural households in the Singida region. Livestock as an integral part of the farming systems in the Singida region was hypothesised to have a positive effect on crop commercialisation through the use of animal traction, manure and income from livestock in crop production. Apart from contributing to the existing empirical literature on the effect of livestock and other factors on agricultural commercialisation as well as the effect of commercialisation on livelihoods, the evidence generated from the study will inform the formulation of policies and strategies for appropriate interventions to enhance commercialisation for better livelihood outcomes in crop-livestock mixed farming systems in SSA.

The paper addresses some key policy-relevant questions including:

i. Does livestock enhance or inhibit crop commercialisation?

ii. What factors other than livestock influence crop commercialisation?

iii. How does commercialisation affect productivity, incomes, food security and poverty?

iv. Does commercialisation and its effects on livelihoods differ between different socioeconomic groups?

The remainder of this study includes a methodology section which describes the conceptual framework, analytical framework and dataset used for the analyses. This is followed by a results section where the findings of the descriptive and econometric analyses are presented and discussed. The discussion section focuses on the effect of livestock and other factors on crop commercialisation and the influence of crop commercialisation on poverty in Singida. The final section presents the conclusions and recommendations emanating from the major findings of the study. 


\subsection{Conceptual framework}

Figure 2.1 presents the major components underlying the analytical framework for our study on the effect of livestock on crop commercialisation and livelihoods of rural households in the Singida region. Commercialisation of crop production in the mixed crop-livestock farming system in the Singida region has been enhanced by livestock-keeping through the provision of farm power for cropland expansion and manure for fertilising crops. Both cropland expansion and fertilisation lead to high crop output and therefore surplus for the market. On the otherhand, the competition for resources such as land for grazing, labour and other resources between livestock and crop production activities can inhibit crop commercialisation. In addition, livestock benefit from crop production through the use of crop residues and by-products from cereals and sunflower seed processing. Since livestock production in the mixed crop-livestock farming system provides a new commercialisation pathway to crop farming, an increasing share of livestock income relative to that from crops would likely suppress the commercialisation tendency for crop-based income sources. Apart from the effects of livestock on crop commercialisation, crop commercialisation is influenced by a multitude

\section{Figure 2.1 Conceptual framework}

of external factors such as policies, institutions and natural hazards among others (Gupta, Vemireddy and Pingali, 2019; Pingali et al., 2019). The last component in our conceptual framework is concerned with the possible impacts of commercialisation on farming households. These impacts may include agricultural productivity, household incomes, food security, nutrition and poverty. Empirical evidence shows that the impacts of commercialisation can be positive (Lerman, 2004; Hailua, Manjure and Aymutc, 2015; Matenga and Hichaambwa, 2017; Isinika et al., 2020) or negative (Fischer and Qaim, 2012; Ntakyo and van den Berg, 2019).

\subsection{Analytical framework}

\subsubsection{Determining the effect of livestock on crop commercialisation}

The effect of livestock on crop commercialisation was determined by first establishing an indicator of crop com In the study area, livestock had different uses. In general, livestock produced meat, milk and eggs that could be consumed by livestock keeping households to improve their food security and nutrition or sold to generate income. They also provided farmyard manure and draft power for pulling farm implements such

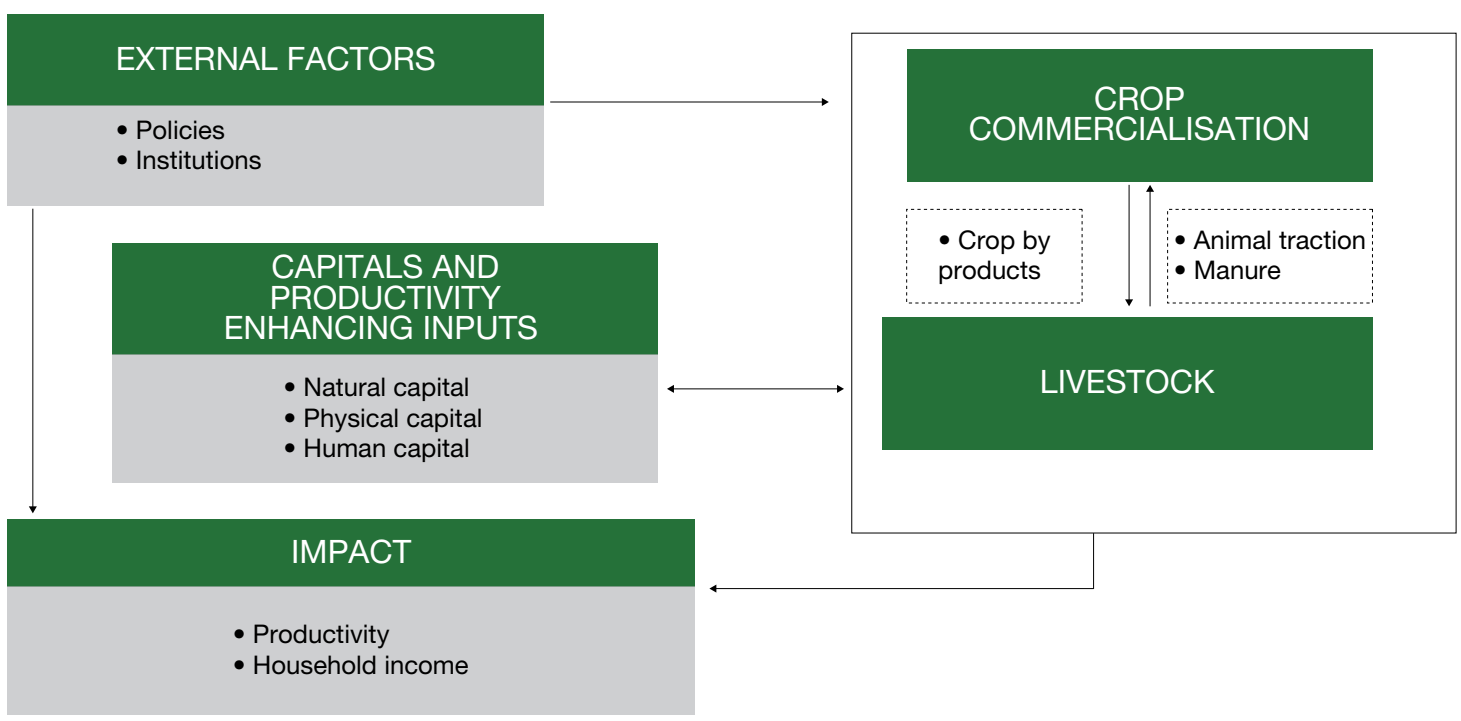

Source: Modified from Mutabazi, Wiggins and Mdoe (2013) 
as tillage, weeding and transportation implements. mercialisation and analysing the influence of livestock on crop commercialisation after controlling for other factors as described below.

\subsubsection{Measuring crop commercialisation}

Agricultural commercialisation has been measured either by examining the extent of the use of purchased inputs (Wiggins et al., 2014; Hagos and Geta, 2016; Kibiti et al., 2016; Alawode, Abegunde and Abdullahi, 2018) and/or volume and value of agricultural output (Leavy and Poulton, 2007; Rahut, Castellanos and Sahoo, 2010; Gebremedhin and Jaleta, 2010; Muriithi and Matz, 2015; Dube and Guveya, 2016). In this paper, we follow Rahut, Castellanos and Sahoo (2010) and Leavy and Poulton (2007), defining the crop commercialisation index as:

$\mathrm{CCl}=\mathrm{GVS}_{\mathrm{ij}} / \mathrm{GVP}_{\mathrm{ij}}$

Where:

$\mathrm{CCl}=$ Crop Commercialisation Index of the ith household

$\mathrm{GVS}_{\mathrm{ij}}=$ Gross value of major crop sales for the ith household during jth season

$\mathrm{GVP}_{\mathrm{ij}}=$ Gross value of major crop production for the ith household during jth season

More than 10 different crops are produced in the Singida region, but only seven major crops in the two sample districts of Iramba and Mkalama were used in the computation of $\mathrm{CCl}$. The seven crops chosen were grown by more than 30 per cent of the sample farmers and at least 30 per cent of the output was marketed, and thus these crops provide a more reliable representation of commercialisation in the region. The crops were maize, sunflower, rice, common bean, sorghum, pearl millet and groundnuts. The computed commercialisation index varies from 0 per cent where no crop output was sold to 100 per cent where all harvested crop output was sold. The sample was divided into four $\mathrm{CCl}$ categories, namely a category of no sales ( 0 per cent) and terciles for the remaining households with low commercialisation as first tercile, medium commercialisation as second terciles and high commercialisation as the third tercile. To examine the effect of livestock and other factors on different groups of farmers, the commercialisation levels were compared for the following categories of households: (i) livestock-keeping and non-livestock-keeping households, (ii) small and medium farmers, (iii) young and old farmers and (iv) $\mathrm{MHH}$ and $\mathrm{FHH}$. The results of these comparisons are presented in the next chapter.

\subsubsection{Determinants of crop commercialisation}

Crop commercialisation index can be expressed either in proportions or in percentages. Both forms of presentation lead to a continuous interval from 0 to 1 and 0 to 100 per cent with both limits included. A two limit Tobit model is appropriate as a corner solution model if there is a pile up at both limits with positive probability. However, according to Wooldridge (2010) if the interest is to estimate the conditional mean of the dependent variable, then a two limit Tobit model can lead to inconsistent parameter estimates. Although a two limit model has been used in similar studies such as Dube and Guveya (2016), Bekele and Alemu (2015)

$$
E(y \mid x)=\Theta(x \beta), \quad 0 \leq y \leq 1
$$

and Kirui and Njiraini (2013), we followed Wooldridge's specification of a model for conditional mean based on logistic or probit function which leads to consistent parameter estimates. The model has been applied in similar studies by Ogunleye et al. (2018). The fractional probit regression model is specified as in equation 1.

Where:

$\mathrm{y}=$ the fraction or proportion of crops commercialised

$\mathrm{E}(\mathrm{y} \mid \mathrm{x})=$ Population conditional mean proportion of crops commercialised

$\Theta(x \beta)=$ normal cumulative distribution function

$\mathrm{B}=$ vector of parameters to be estimated

The vector $\mathrm{x}$ represents explanatory and control variables categorised into household and household head factors (sex of household head, age of household, education of household head, household size, total crop land, non-farm income), an information technology variable (use of mobile phone), physical factors (distance to nearest all weather road) and agricultural technology variables (use of modern tillage implements such as animal traction and tractor, use of purchased seed, use of inorganic fertilisers, use of organic fertiliser or manure, and use of pesticides). The aim is to determine the partial effects of the $\mathrm{x}$ variables on the mean proportion of crops commercialised.

The parameters of equation 1 are estimated by Bernoulli Quasi Maximum Likelihood Estimation fractional probit regression. The specification of the variables used for the fractional probit regression is presented in Annex 1. 


\subsubsection{Determining the effect of livestock and other factors on poverty among rural households}

The determination of the effect of livestock and other factors on the livelihoods of rural households comprised of two steps. The first step was the development of livelihood indicators while the second step involved the measurement of the effect of livestock and other factors on the livelihoods of the sample households.

\subsubsection{Developing poverty indicators}

The common approaches in the literature to measure the level of livelihood use income, assets, food security, subjective well-being, or multidimensional poverty (Alkire, Roche and Vaz, 2015). This paper uses the Multidimensional Poverty Index (MPI) as proposed by Alkire, Roche and Vaz (2015) and Alkire and Santos (2014). The MPI uses a set of vulnerability indicators to determine the incidence of poverty (headcount) and the intensity of poverty (degree of deprivation). At the population level these two indicators are combined to compute the MPI. A poverty cut-off point of 33.3 per cent identified people whose deprivation score exceeds this threshold as 'multidimensional poor' (Alkire, Roche and Vaz, 2015). A household is considered "MPI poor" if its score is above the 0.33 (or 33 per cent) cut-off point, and not MPI poor otherwise. Hence, the overall $\mathrm{MPI}$ represents a proportion of the sample which is poor. Being representative of the population from which the sample is drawn, higher scores represent more deprivation, hence deeper poverty. The entire list of indicators that were used to compute the MPI is summarised in Annexes 2a and 2b.

\subsubsection{Determinants of poverty status}

The influence of livestock on household poverty status can take the following pathways: the productivity pathway through provision of organic fertiliser or animal traction and income pathway through the sale of live animals and livestock products. Given the limitations of recall in estimating livestock income we used Tropical Livestock Units (TLU) under the assumption that they have a high correlation with livestock income. According to Engida, Gathiga and Karugia (2015), livestock assets provide a flow of income from sales of animals and products such as meat, eggs and milk, but to fully account for livestock income, it is necessary to include value of non-monetary exchanges (barter) and household consumption less the expenditure related to livestock production in the form of labour, feeds and veterinary services (Pica-Camara et al., 2011). While in absolute terms it is expected that the higher the livestock assets owned the higher the income flow, there is no clear evidence that the share of livestock income to total livestock income is dependent on the size of livestock assets (Pica-Camara et al., 2011). The technology variables are reflected in the commercialisation index and are therefore not included in the model.

A probit model is used to determine the likelihood of a household being MPI poor given a set of attributes as specified below. A latent model indicating the household poverty status is presented in equation 2.

$$
\begin{aligned}
& \mathrm{V}^{*} \text { is unobservable and is linked to MPI as follows" } \\
& p(M P I=1 \mid x)=p\left(v^{*}<0 \mid x\right)=p[(x \beta+\mu) \mid x<0] \\
& =p(\mu<-x \beta \mid x)=\Theta(-x \beta) \\
& v *=x \beta+u: u \mid x \sim N\left(0, \sigma^{2}\right)
\end{aligned}
$$

Where:

$\Theta(-\mathrm{x} \beta)=$ the standard normal cumulative distribution function. $\mathrm{x}=$ vector of explanatory variables whose details are presented in Annex 3.

The probit model presented in equation 3 is estimated by Maximum Likelihood method. Annex 3 presents the specification of the variables and expected signs of the coefficients for equation.

\subsection{Data}

The paper uses survey data collected for the APRA sunflower commercialisation study in the Iramba and Mkalama districts in the Singida region in Tanzania. The survey involved 600 households (13.6 per cent femaleheaded and 86.4 per cent male-headed) selected using a two-stage sampling design with stratification. The two strata were Iramba and Mkalama districts from which eight and seven villages respectively were selected separately with probability proportional to size, while 40 households were selected from each village selected in stage by simple random sampling. The Singida region was purposively selected not only because it is a major sunflower producing region but also due to its long history of sunflower production. Meanwhile, the Iramba and Mkalama districts were purposively selected because they have been leading in sunflower production, accounting for nearly 50 per cent of sunflowers produced in the Singida region (NBS, 2017; URT, 2020). Singida is located in central Tanzania, between latitude $30^{\circ} 52^{\prime}$ and $70^{\circ} 34^{\prime}$ south of the equator and longitudes $220^{\circ} 27^{\prime}$ and $350^{\circ} 26^{\prime}$ east of Greenwich. The region has six district councils (Singida rural, Singida urban, Itigi, Manyoni, Mkalama and Iramba). Iramba District Council represents farmers operating on the plateau, above the rift valley while Mkalama District Council represents farmers in the rift valley. A map showing the study districts is presented in Annex 4. 


\section{FINDINGS}

\subsection{Findings of the descriptive analyses}

\subsubsection{Livestock keeping, ownership and use}

As highlighted in the introduction, livestock keeping is an integral part of the farming systems in the Singida region. Local chickens were the most common livestock type, raised by 80 per cent of the sampled households. Cattle, goats, sheep and pigs were raised by approximately 70, 45, 36 and 4 per cent of the sampled households respectively. With respect to cattle, two categories of cattle keepers exist in Singida region, owners and caretakers who do not own but raise the cattle on behalf of the owners. Owners and caretakers account for 92.1 and 7.9 per cent of the livestock keeping households, respectively. Evidence from focus group discussions and key informant interviews showed that livestock, especially cattle, are kept as store of wealth. Apart from keeping cattle as store of wealth, the owners of cattle under caretakers benefit from cattle sales and saving herding labour costs. The decision to sell cattle occurs when the cattle owner needs cash income for farming and/or other household needs. On the other hand, the cattle caretakers benefit from drinking and selling milk as well as draft power and cattle manure for crop production (Isinika and Mwajombe, 2019).

Imbalance in ownership of livestock was evident in this study. For example, FHHs, households headed by SSF, and young farmers seemed to be more disadvantaged in terms of the number of animals/birds per household than $\mathrm{MHH}$ and households headed by MSF and old farmers (Table 3.1). The pattern was the same with respect to percentages of households owning the different types of livestock, except in the case of farm size category where the percentages of SSFs owning different types of livestock is significantly higher than MMFs (Table 3.1).

In the study area, livestock had different uses. In general, livestock produced meat, milk and eggs that could be consumed by livestock keeping households to improve their food security and nutrition or sold to generate income. They also provided farmyard manure and draft power for pulling farm implements such as tillage, weeding and transportation implements.

\subsubsection{Land ownership and use}

Inequality in land ownership between different socioeconomic groups in the study area was evident.

Table 3.1: Ownership of livestock/birds by farmer category

\begin{tabular}{|l|l|l|l|l|l|l|l}
\hline $\begin{array}{l}\text { Type of } \\
\text { livestock }\end{array}$ & SSF & MSF & FHH & MHH & MHH & MHH \\
\hline
\end{tabular}

\section{Average number of livestock per household:}

\begin{tabular}{|c|c|c|c|c|c|c|c|}
\hline Cattle & 5.3 & $18.1^{\star \star \star}$ & 3.5 & $8.2^{\star \star \star}$ & 5.8 & 8.0 & 7.5 \\
\hline Goats & 3.2 & $9.1^{\star \star \star}$ & 1.8 & $4.6^{\star \star \star}$ & 2.8 & $4.6^{\star \star}$ & 4.2 \\
\hline Sheep & 1.5 & $6.4^{\star \star \star}$ & 1.0 & $2.5^{\star \star}$ & 1.3 & 2.6 & 2.3 \\
\hline Pigs & 0.1 & $0.3^{\star \star \star}$ & 0.12 & 0.14 & 0.02 & $0.2^{\star \star \star}$ & 0.1 \\
\hline Chickens & 7.8 & $12.9^{\star \star \star}$ & 6.5 & 9.1 & 8.4 & 8.8 & 8.7 \\
\hline \multicolumn{8}{|c|}{ Percentage of households owning: } \\
\hline Cattle & 64.6 & $94.3^{\star \star \star}$ & 44.6 & $73.4^{\star \star \star}$ & 65.6 & 70.6 & 69.4 \\
\hline Goats & 41.65 & $64.8^{\star \star \star}$ & 25.6 & $48.6^{\star \star \star}$ & 48.4 & $35.4^{\star \star}$ & 45.5 \\
\hline Sheep & 31.5 & $55.2^{\star \star \star}$ & 18.3 & $38.4^{\star \star \star}$ & 21.5 & $39.7^{\star \star \star}$ & 35.7 \\
\hline Pigs & 2.7 & $11.4^{\star \star \star}$ & 4.9 & 4.1 & 1.5 & $4.9^{\star \star}$ & 4.2 \\
\hline Chickens & 78.6 & $86.7^{\star}$ & 69.5 & $81.7^{\star \star}$ & 75.6 & 81.4 & 80.0 \\
\hline
\end{tabular}

Note: ${ }^{\star}=$ difference is significant at $P=0.1 ;{ }^{* \star}=$ difference is significant at $P=0.05$;

*** $=$ difference is significant at $P=0.01$

Source: Authors' own 
$\mathrm{MHH}$ and households headed by MSF, old farmers and livestock keepers owned more agricultural land than $\mathrm{FHH}$ and households headed by SSF, young farmers and non-livestock keepers (Table 3.2). This finding is supported by the results of the focus group discussions carried out with different socioeconomic groups (women, men and youth) in 15 villages (Isinika and Mwajombe, 2019).

Besides livestock keeping indicated above, land in the study area was used for crop production. The land allocated to different crops is shown in Table 3.3. It is evident from Table 3.3 that MSF allocated significantly more land than SSF for all major crops except common beans. Interestingly, FHHs who allocated significantly less land to most crops allocated significantly more land to common bean production than $\mathrm{MHH}$ in the 2017/18 farming season. No significant difference was observed in land allocated to most crops between young and old farmers except in land allocated to common beans whereas the land allocated by old farmers was twice the land allocated by young farmers.
Non-livestock keepers who owned less land than livestock keepers also allocated less land to all crops than livestock keepers.

\subsubsection{Ownership of other productive assets}

Sample farmers owned several productive assets ranging from basic tools with small value such as hand hoes, axes and cutlasses to assets with big value such as tractors, ploughs, animal carts, water pumps and sprayers. Almost all households owned the basic tools while the assets with big value were owned by relatively few households (Table 3.4). Tractors - which had the highest value among the assets - were owned by the smallest percentage of farmers. Like ownership of land, imbalance in ownership of other productive assets of big value was evident. In general, the percentage of $\mathrm{MHH}$ s and households headed by MSF and livestock keepers owned productive assets of higher value than those of $\mathrm{FHHs}$ and households headed by young farmers and non-livestock keepers, respectively (Table 3.4). The finding that ownership of productive assets of higher value is higher among $\mathrm{MHH}$ than $\mathrm{FHHs}$

Table 3.2: Land owned per household (ha) by farmer category.

\begin{tabular}{|l|l|l|l|l|l|l|l|l|}
\hline & \multicolumn{2}{|l|}{$\begin{array}{l}\text { Farm size } \\
\text { Item }\end{array}$} & \multicolumn{2}{l|}{$\begin{array}{l}\text { Gender of household } \\
\text { head }\end{array}$} & Age category & \multicolumn{2}{l|}{ Livestock keeping } \\
\hline & SSF & MSF & FHH & MHH & $\begin{array}{l}\text { Young } \\
\text { farmer }\end{array}$ & $\begin{array}{l}\text { Old } \\
\text { farmer }\end{array}$ & $\begin{array}{l}\text { Livestock } \\
\text { keepers }\end{array}$ & $\begin{array}{l}\text { Non-livestock } \\
\text { keepers }\end{array}$ \\
\hline Mean land area & 2.3 & $8.2^{\star \star \star}$ & 2.0 & $3.5^{\star \star \star}$ & 2.9 & $3.4^{\star}$ & 3.9 & $1.9^{\star \star \star}$ \\
\hline Median & 2.1 & 7.3 & 1.6 & 2.6 & 2.1 & 2.6 & 3.2 & 1.6 \\
\hline Maximum & 5.0 & 19.0 & 7.7 & 19.0 & 16.2 & 19.0 & 19.0 & 10.9 \\
\hline Minimum & 0.1 & 5.1 & 0.2 & 0.1 & 0.1 & 0.2 & 0.1 & 0.2 \\
\hline
\end{tabular}

Note: ${ }^{*}=$ difference is significant at $\mathrm{P}=0.1 ;{ }^{\star \star}=$ difference is significant at $\mathrm{P}=0.05$;

${ }^{\star * *}=$ difference is significant at $P=0.01$

Source: Authors' own

Table 3.3: Mean land area allocated to different crops per household (ha) by farmer category in the 2017/18 farming season

\begin{tabular}{|c|c|c|c|c|c|c|c|c|}
\hline \multirow[t]{2}{*}{ Item } & \multicolumn{2}{|c|}{$\begin{array}{l}\text { Farm size } \\
\text { category }\end{array}$} & \multicolumn{2}{|c|}{$\begin{array}{l}\text { Gender of household } \\
\text { head }\end{array}$} & \multicolumn{2}{|c|}{ Age category } & \multicolumn{2}{|c|}{ Livestock keeping } \\
\hline & SSF & MSF & FHH & MHH & $\begin{array}{l}\text { Young } \\
\text { farmer }\end{array}$ & $\begin{array}{l}\text { Old } \\
\text { farmer }\end{array}$ & $\begin{array}{l}\text { Livestock } \\
\text { keepers }\end{array}$ & $\begin{array}{l}\text { Non-livestock } \\
\text { keepers }\end{array}$ \\
\hline Maize & 1.1 & $2.7^{\star \star \star}$ & 0.9 & $1.4^{\star \star}$ & 1.2 & 1.2 & 1.6 & $0.8^{\star \star \star}$ \\
\hline Rice & 0.8 & $2.6^{\star \star \star}$ & 0.3 & $1.5^{\star \star}$ & 1.1 & 1.1 & 1.6 & $0.6^{\star \star \star}$ \\
\hline Sorghum & 0.8 & $2.2^{\star \star \star}$ & 0.7 & $1.1^{\star}$ & 0.8 & 0.8 & 1.1 & $0.7^{\star \star}$ \\
\hline Pear millet & 1.3 & $2.4^{\star \star}$ & 1.2 & 1.6 & 1.5 & 1.5 & 1.7 & $0.7^{\star \star \star}$ \\
\hline Sunflower & 0.8 & $2.8^{\star \star \star}$ & 0.7 & $1.3^{\star \star}$ & 1.2 & 1.2 & 1.4 & $0.7^{\star \star \star}$ \\
\hline Groundnuts & 0.3 & $0.5^{\star}$ & 0.3 & 0.4 & 0.4 & 0.4 & 0.4 & 0.3 \\
\hline Common beans & 0.4 & $0.9^{\star \star}$ & 1.1 & $0.5^{\star}$ & 0.3 & 0.3 & 0.6 & 0.4 \\
\hline
\end{tabular}

Note: ${ }^{\star}=$ difference is significant at $P=0.1 ;{ }^{* \star}=$ difference is significant at $P=0.05$;

${ }^{\star \star *}=$ difference is significant at $P=0.01$

Source: Authors' own 
supports the findings from the focus group discussions carried out in the village where the household survey was conducted (Isinika and Mwajombe, 2019).

\subsubsection{Use of modern tillage implements and productivity enhancing inputs and services}

With the exception of animal traction, purchased seeds and livestock manure, use of modern tillage implements and productivity enhancing inputs and extension services was quite low as evidenced by the percentages of sample households using them (Table 3.5). Apart from low use, the percentages of $\mathrm{FHH}$ and households headed by SSF, young farmers and nonlivestock keepers that used modern tillage implements and productivity enhancing inputs were significantly lower than those of $\mathrm{MHHs}$ and households headed by old farmers and livestock keepers (Table 3.5). This suggests a higher likelihood of these households achieving lower crops yields than the $\mathrm{MHH}$ and households headed by old farmers and livestock keepers. However, it is interesting to note that crop yields achieved by $\mathrm{FHH}$ s were significantly higher than those achieved by MHHs as indicated in Section 3.1.5. This is contrary to the findings of many previous studies. Most studies report higher yields for $\mathrm{MHH}$ s than $\mathrm{FHH}$ (Peterman et al., 2011; Challa and Mahendran, 2015; Oseni et al., 2015; Slavchevska, 2015; Ogunniyi and Ajao, 2010; Gebre et al., 2021;) while few studies report insignificant differences in crop yields between MHHs and FHHs (Akresh, 2005; Masterson, 2007; Croppenstedt, Goldtein and Ross, 2013). The relatively higher crop yields obtained by $\mathrm{FHH}$ compared with $\mathrm{MHH}$ s might be due to differences in crop husbandry practices such as planting time, spacing and weeding frequency and timely weeding.

Table 3.4: Percentage of households owning different productive assets by farmer category

\begin{tabular}{|l|l|l|l|l|l|l|l|l|}
\hline & \multicolumn{2}{|l|}{$\begin{array}{l}\text { Farm size } \\
\text { Item }\end{array}$} & SSF & MSF & FHH & Fead & \multicolumn{2}{l|}{ Livestock keeping } \\
\hline & & & MHH & $\begin{array}{l}\text { Young } \\
\text { farmer }\end{array}$ & $\begin{array}{l}\text { Old } \\
\text { farmer }\end{array}$ & $\begin{array}{l}\text { Livestock } \\
\text { keepers }\end{array}$ & $\begin{array}{l}\text { Non-livestock } \\
\text { keepers }\end{array}$ \\
\hline Tractors & 0.2 & 1.0 & 0.0 & 0.4 & 0.0 & 0.4 & 0.6 & 0.2 \\
\hline Ploughs & 51.6 & $84.8^{\star \star \star}$ & 41.3 & $59.7^{\star \star \star}$ & 50.4 & $59.2^{\star}$ & 77.0 & $10.1^{\star \star \star}$ \\
\hline Carts & 14.1 & $50.5^{\star \star \star}$ & 22.6 & $6.3^{\star \star \star}$ & 18.0 & 21.0 & 28.0 & $2.8^{\star \star \star}$ \\
\hline Water pumps & 1.2 & 2.9 & 0.0 & 1.7 & 0.8 & 1.7 & 1.7 & 1.1 \\
\hline Sprayers & 5.5 & $24.8^{\star \star \star}$ & 5.0 & 9.5 & 6.9 & 9.4 & 10.8 & $4.5^{\star \star}$ \\
\hline
\end{tabular}

Note: ${ }^{*}=$ difference is significant at $P=0.1 ;{ }^{* \star}=$ difference is significant at $P=0.05$;

${ }^{\star \star \star}=$ difference is significant at $\mathrm{P}=0.01$

Source: Authors' own

Table 3.5: Percentage of households using modern tillage implements and productivity enhancing inputs and services

\begin{tabular}{|c|c|c|c|c|c|c|c|c|}
\hline \multirow[t]{2}{*}{ Item } & \multicolumn{2}{|c|}{$\begin{array}{l}\text { Farm size } \\
\text { category }\end{array}$} & \multicolumn{2}{|c|}{$\begin{array}{l}\text { Gender of household } \\
\text { head }\end{array}$} & \multicolumn{2}{|c|}{ Age category } & \multicolumn{2}{|c|}{ Livestock keeping } \\
\hline & SSF & MSF & FHH & MHH & $\begin{array}{l}\text { Young } \\
\text { farmer }\end{array}$ & $\begin{array}{l}\text { Old } \\
\text { farmer }\end{array}$ & $\begin{array}{l}\text { Livestock } \\
\text { keepers }\end{array}$ & $\begin{array}{l}\text { Non-livestock } \\
\text { keepers }\end{array}$ \\
\hline \multicolumn{9}{|c|}{ Modern tillage implements: } \\
\hline Tractors & 7.4 & 13.5 & 4.9 & 8.9 & 7.7 & 8.6 & 6.5 & $12.5^{\star \star}$ \\
\hline Animal traction & 35.0 & 50.7 & 45.8 & $63.3^{\star \star \star}$ & 48.1 & 48.5 & 63.3 & $24.6^{\star \star \star}$ \\
\hline \multicolumn{9}{|c|}{ Productivity enhancing inputs and extension services: } \\
\hline Purchased seeds & 84.2 & 88.2 & 74.6 & $86.7^{\star \star}$ & 84.1 & 87.8 & 84.3 & 86.5 \\
\hline Manure & 37.4 & $50.5^{\star \star}$ & 29.3 & $41.3^{\star \star}$ & 32.3 & $41.6^{\star \star}$ & 46.0 & $25.0^{\star \star \star}$ \\
\hline Inorganic fertiliser & 85.6 & 86.7 & 12.2 & 14.4 & 15.3 & 13.8 & 12.6 & $17.8^{*}$ \\
\hline Pesticides & 14.0 & 19.0 & 12.3 & 15.4 & 13.0 & 15.6 & 14.5 & 16.1 \\
\hline Extension service & 16.5 & 21.0 & 16.3 & 17.5 & 14.7 & 18.1 & 17.3 & 17.5 \\
\hline
\end{tabular}

Note: ${ }^{*}=$ difference is significant at $P=0.1 ;{ }^{* *}=$ difference is significant at $P=0.05$;

${ }^{\star * \star}=$ difference is significant at $\mathrm{P}=0.01$

Source: Authors' own 


\subsubsection{Crop productivity}

Like the use of modern implements and productivity enhancing inputs, productivity (yields) of crops achieved in the 2017/18 farming season varied across different categories of famers (Table 3.6). However, the difference was not significant for most crops and farmer categories except rice where yields achieved by $\mathrm{FHH}$ s were significantly higher than those achieved by $\mathrm{MHH}$ and groundnuts. Yields achieved by old farmers were significantly higher than those achieved by young farmers.

\subsubsection{Crop sales}

In the 2017/18 farming season, crop sales varied across crops and across different farmer categories (Table 3.7). In general, sales were relatively higher for maize, rice and sunflower. Irrespective of the level of sales across the crops, there were significant differences in sales between different farmer categories for most crops (Table 3.7). MSF, MHHs, old farmers and non-livestock keepers had significantly higher crop sales than SSF, FHHs, young farmers and livestock keepers, respectively.

\subsubsection{Livelihood activities and incomes in Singida}

This section summarises findings concerning livelihood activity patterns and income level in the study area. Starting with crop and livestock production, Table 3.8 shows average cultivated area under production of major crops and percentage of households growing the crop. The leading crops in terms of both acreage per household and proportion of sample households growing them were maize, sunflower and sorghum. The portfolio of the major crops in Table 3.8 comprises drought-tolerant crops including sorghum and pear millet which are grown in semi-arid regions such as Singida to cope with climate-related risks (Lema and Majule, 2009; Mkonda and He, 2018). As indicated in

Table 3.6: Crop yields (kg/ha) for major crops grown in the 2017/18 farming season by farmer category

\begin{tabular}{|c|c|c|c|c|c|c|c|c|}
\hline \multirow[t]{2}{*}{ Item } & \multicolumn{2}{|c|}{$\begin{array}{l}\text { Farm size } \\
\text { category }\end{array}$} & \multicolumn{2}{|c|}{$\begin{array}{l}\text { Gender of household } \\
\text { head }\end{array}$} & \multicolumn{2}{|c|}{ Age category } & \multicolumn{2}{|c|}{ Livestock keeping } \\
\hline & SSF & MSF & FHH & MHH & $\begin{array}{l}\text { Young } \\
\text { farmer }\end{array}$ & $\begin{array}{l}\text { Old } \\
\text { farmer }\end{array}$ & $\begin{array}{l}\text { Livestock } \\
\text { keepers }\end{array}$ & $\begin{array}{l}\text { Non-livestock } \\
\text { keepers }\end{array}$ \\
\hline Maize & 1022.4 & 1071.1 & 1184.7 & 1005.3 & 990.0 & 1041.3 & 996.3 & 1118.1 \\
\hline Rice & 2068.6 & 2335.4 & 3481.5 & $2019.6^{\star \star}$ & 2420.9 & 2018.4 & 2110.5 & 2358.0 \\
\hline Sorghum & 691.5 & 568.7 & 727.2 & 658.5 & 258.7 & 341.6 & 696.8 & 588.9 \\
\hline Pear millet & 712.5 & 750.8 & 657.7 & 731.0 & 704.8 & 721.9 & 694.6 & 837.5 \\
\hline Sunflower & 654.4 & 553.4 & 475.3 & 657.6 & 658.9 & 622.6 & 641.9 & 602.6 \\
\hline Groundnuts & 373.5 & 335.3 & 258.0 & 380.6 & 119.2 & $399.5^{\star \star}$ & 356.6 & 383.4 \\
\hline Common beans & 306.1 & 405.5 & 163.0 & 334.7 & 258.7 & 341.6 & 351.1 & 268.0 \\
\hline
\end{tabular}

Note: ${ }^{*}=$ difference is significant at $\mathrm{P}=0.05$

Source: Authors' own

Table 3.7: Crop sales (kg per households) for major crops sold in 2017/18 farming season by farmer category

\begin{tabular}{|l|l|l|l|l|l|l|l|l|}
\hline & \multicolumn{3}{|l|}{$\begin{array}{l}\text { Farm size } \\
\text { category }\end{array}$} & \multicolumn{2}{l|}{$\begin{array}{l}\text { Gender of household } \\
\text { head }\end{array}$} & \multicolumn{2}{l|}{ Age category } & \multicolumn{2}{l|}{ Livestock keeping } \\
\hline & SSF & MSF & FHH & MHH & $\begin{array}{l}\text { Young } \\
\text { farmer }\end{array}$ & $\begin{array}{l}\text { Old } \\
\text { farmer }\end{array}$ & $\begin{array}{l}\text { Livestock } \\
\text { keepers }\end{array}$ & $\begin{array}{l}\text { Non- } \\
\text { livestock } \\
\text { keepers }\end{array}$ \\
\hline Maize & 14.9 & $22.6^{\star \star}$ & 158.8 & $427.5^{\star \star \star}$ & 554.4 & $349.1^{\star}$ & 474.7 & $186.4^{\star \star \star}$ \\
\hline Rice & 28.6 & $46.1^{\star \star}$ & 390.00 & $1505.3^{\star \star \star}$ & 2470.1 & 898.0 & 1756.2 & $465.6^{\star \star \star}$ \\
\hline Sorghum & 11.8 & $5.5^{\star \star}$ & 31.2 & $103.1^{{ }^{\star *}}$ & 226.9 & $64.4^{\star \star}$ & 100.4 & 72.7 \\
\hline Pear millet & 12.0 & $28.9^{\star \star}$ & 60.6 & $243.6^{\star \star}$ & 212.0 & 200.6 & 242.5 & $36.0^{\star \star}$ \\
\hline Sunflower & 333.4 & $1056.2^{\star \star}$ & 210.4 & $530.1^{\star \star}$ & 605.8 & $453.2^{\star}$ & 556.1 & $276.6^{\star \star \star}$ \\
\hline Groundnuts & 8.7 & 10.4 & 75.0 & $13.4^{\star \star}$ & 3.3 & 24.4 & 8.0 & $83.3^{\star \star \star}$ \\
\hline Common beans & 8.3 & $17.9^{\star}$ & 1.7 & $41.3^{\star \star}$ & 57.1 & 36.8 & 43.0 & 25.8 \\
\hline
\end{tabular}

Note: ${ }^{*}=$ difference is significant at $\mathrm{P}=0.1 ;{ }^{* \star}=$ difference is significant at $\mathrm{P}=0.05$;

${ }^{* * *}=$ difference is significant at $P=0.01$

Source: Authors' own 
Table 3.9, different species of livestock that differ in resilience to climatic and environmental changes were kept. For example, as opposed to cattle and sheep, goats could thrive by browsing on remaining shrubs. This species composition is a probably a strategy to cope with risks associated with drought (Speranza, 2010; Opiyo et al., 2015).

Table 3.10 shows the number and proportion of sample households involved in non-farm activities in 2017/18. The leading non-farm activity in terms of percentage of households involved was wage employment followed by self-employment.

It is important for rural poverty reduction policies to understand the role non-farm and farm sources of income play in household incomes in rural areas. This could help to determine, for example how to balance public resource utilisation between promoting increases in agricultural productivity on the one hand and providing services to non-farm activities on the other. It is notable from Figure 3.1 that crop income and livestock income contributed to 40 per cent and 20.6 per cent of total household income, respectively. The remaining 39.4 per cent was contributed to nonfarm income. The non-farm income comprised wages (14.6 per cent), self-employment (13.9 per cent) and transfers (10.7 per cent). There was no significant difference between crop production and non-farm activities in the contribution to total household income in $2017 / 18$. Although the 21 per cent contribution of livestock was less than the contribution of crops to the total household income, it enhanced crop production through provision of manure and animal traction which are often not accounted for in the value of livestock.

Table 3.11 shows that the contribution of the different income sources to total household income varied across farmer categories however the differences were not significant. Contributions of crop and livestock incomes to incomes of households headed

Table 3.8: Average cultivated land area under crop production and percentage of households growing the crop

\begin{tabular}{|l|l|l|}
\hline Crop & Ha per household & Percentage of households growing \\
\hline Maize & 3.38 & 83.9 \\
\hline Rice & 3.35 & 6.0 \\
\hline Sorghum & 2.51 & 55.6 \\
\hline Pear millet & 3.70 & 7.0 \\
\hline Sunflower & 3.08 & 71.1 \\
\hline Groundnuts & 0.95 & 8.8 \\
\hline Common beans & 1.27 & 11.6 \\
\hline
\end{tabular}

Source: Authors' own

Table 3.9: Average number of livestock and percentage of households keeping the livestock

\begin{tabular}{|l|l|l|}
\hline Livestock type & Number per household & Percentage of households keeping \\
\hline Cattle & 7.5 & 69.4 \\
\hline Goats & 4.2 & 45.5 \\
\hline Sheep & 2.3 & 35.7 \\
\hline Pigs & 0.1 & 4.2 \\
\hline Chickens & 8.7 & 80.0 \\
\hline
\end{tabular}

Source: Authors' own

Table 3.10: Distribution of sample households by type of non-farm income activity

\begin{tabular}{|l|l|l|}
\hline Non-farm income activities & Number of households & $\%$ t \\
\hline Wages & 219 & 37.0 \\
\hline Self-employment & 209 & 35.0 \\
\hline Remittances & 161 & 27.0 \\
\hline Total non-farm & 589 & 100.0 \\
\hline
\end{tabular}

Source: Authors' own 
by MSF were relatively higher than their contribution to incomes of other farmer categories. The contribution of non-farm income to incomes of $\mathrm{FHH}$ was relatively higher than its contribution to incomes of households of other farmer categories (Table 3.11). Wage income is generated mainly from seasonal wage work on other farms and was especially important for $\mathrm{FHH}$ and households headed by SSF and young farmers, compared to $\mathrm{MHH}$ and households headed by MSF and old farmers, respectively. The seasonal wage work is probably used as a strategy to cope with the risk of crop failure due to drought as reported by studies conducted in semi-arid areas elsewhere (Anderson et al., 2016; Gautam and Andersen, 2017, 2016; Blackmorea et al., 2021). Self-employment activities, comprising a range of enterprises from retail trade to brick making, local beer brewing and handicrafts were predominant among young farmers. Transfer incomes (principally comprising remittances) played a relatively small part in livelihoods of households in Singida and were highly important to incomes of $\mathrm{FHH}$.

\subsubsection{Crop commercialisation}

This section presents commercialisation levels of individual major crops in the study area and an overall CCl. The individual crop commercialisation levels varied across crops and across different categories of farmers (Table 3.12). Sunflower appeared to be the highest commercialised crop with commercialisation levels above 60 per cent across all farmer categories. Commercialisation levels of all other crops were below 50 per cent. In general, FHH and households headed by SSF, old farmers and non-livestock keepers had relatively

Figure 3.1: Total income portfolios for the whole sample

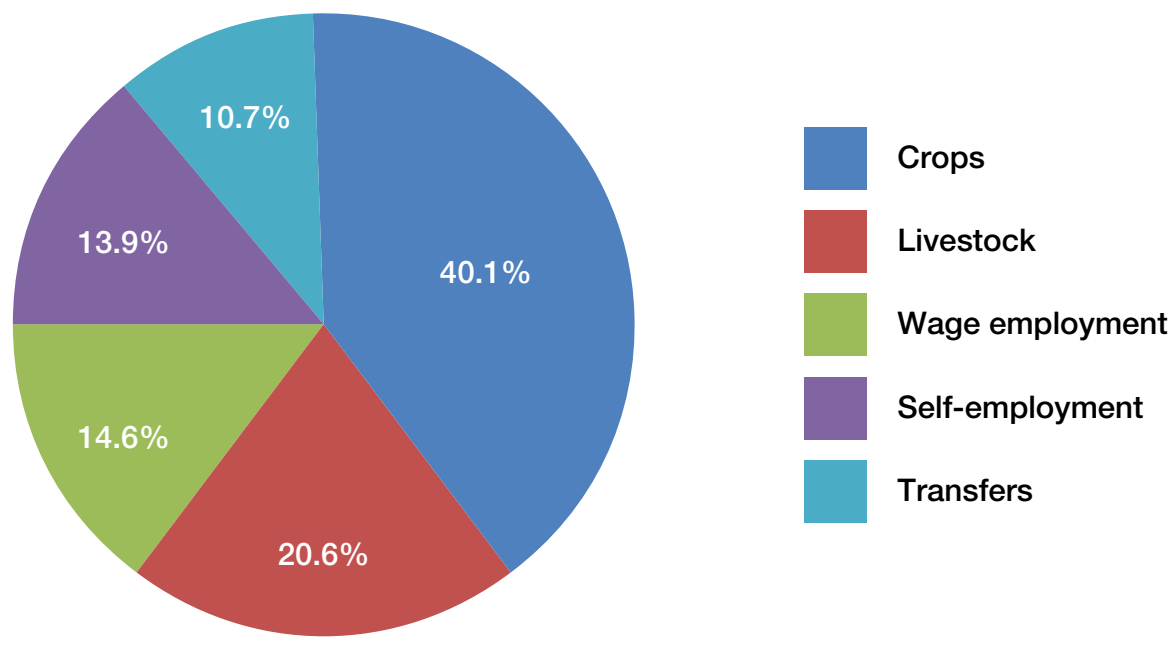

Source: Authors' own

Table 3.11: Pattern of income portfolios (percentage of total income) by farmer category.

\begin{tabular}{|l|l|l|l|l|l|l|l|}
\hline & \multicolumn{9}{|l|}{ Income source } & \multicolumn{5}{l|}{ Farmer category } & $\begin{array}{l}\text { Whole } \\
\text { sample }\end{array}$ \\
\hline & SSF & MSF & FHH & MHH & YF & OF & \\
\hline Crops & 39.8 & 41.5 & 41.0 & 40.0 & 40.7 & 39.9 & 40.1 \\
\hline Livestock & 19.3 & 27.7 & 14.5 & 21.6 & 20.7 & 20.6 & 20.6 \\
\hline Wages & 16.2 & 6.3 & 16.5 & 14.3 & 16.4 & 14.1 & 14.6 \\
\hline Self-employment & 13.6 & 15.4 & 10.5 & 14.5 & 17.3 & 13.0 & 13.9 \\
\hline Remittances & 11.0 & 9.1 & 17.5 & 9.7 & 4.9 & 12.4 & 10.7 \\
\hline Total non-farm & 40.8 & 30.8 & 44.5 & 38.5 & 38.6 & 39.5 & 39.2 \\
\hline Total & 100.0 & 100.0 & 100.0 & 100.0 & 100.0 & 100.0 & 100.0 \\
\hline
\end{tabular}

Note: YF = young farmer, OF = old farmer

Source: Authors' own 
lower commercialisation levels than $\mathrm{MHH}$ and households headed by MSF, young farmers and livestock keepers.

The individual crop commercialisation indices were used to compute the $\mathrm{CCl}$ as described in the methodology. The mean CCl for the whole sample was 59.2 per cent. The CCl varied significantly across different categories of farmers. As indicated in Table 3.13, the $\mathrm{CCl}$ for $\mathrm{MHH}$ and households headed by MSF, young farmers and livestock keepers were significantly higher than the $\mathrm{CCl}$ for $\mathrm{FHH}$ and households headed by SSF, old farmers and non-livestock keepers. The major reason for the difference in $\mathrm{CCl}$ is probably low productivity resulting from differences in the use of productivity enhancing inputs such as improved seeds and fertiliser as well as the use of modern farm implements as indicated earlier. These results support the findings by Isinika et al. (2020), Mdoe et al. (2020), Mutabazi, Wiggins and Mdoe (2013) and Wiggins et al. (2011).

\subsubsection{Household income, food security and poverty across different categories of farmer}

As pointed out earlier, agricultural commercialisation remains widely pursued in low-income countries to improve agricultural productivity, farm income, food security, and reduce poverty among farmers. This section presents the distribution of total household income and livelihood outcomes across different categories of farmers. Household income is an

Table 3.12: Mean commercialisation indices (per cent) for major crops grown in the $2017 / 18$ farming season by farmer category

\begin{tabular}{|l|l|l|l|l|l|l|l|l|}
\hline & \multicolumn{2}{|l|}{$\begin{array}{l}\text { Farm size } \\
\text { Item }\end{array}$} & SSF & MSF & FHH & \multicolumn{2}{l|}{$\begin{array}{l}\text { Sex category of } \\
\text { household head }\end{array}$} & \multicolumn{2}{l|}{$\begin{array}{l}\text { Age category of } \\
\text { farmer }\end{array}$} & \multicolumn{2}{l|}{$\begin{array}{l}\text { Livestock keeping } \\
\text { category }\end{array}$} \\
\hline & & & & & $\begin{array}{l}\text { Young } \\
\text { keeper }\end{array}$ & Old & $\begin{array}{l}\text { Non- } \\
\text { livestock } \\
\text { keeper }\end{array}$ \\
\hline Maize & 14.9 & $22.6^{\star \star \star}$ & 13.7 & 16.6 & 20.0 & 15.1 & 17.2 & 14.0 \\
\hline Rice & 28.6 & $46.1^{\star}$ & 21.1 & 34.8 & 52.8 & $24.8^{\star}$ & 36.7 & $18.8^{\star}$ \\
\hline Sorghum & 11.8 & $5.5^{\star \star}$ & 9.7 & 10.7 & 15.7 & $9.5^{\star}$ & 9.4 & $13.8^{\star}$ \\
\hline Pear millet & 12.0 & $28.9^{\star \star}$ & 13.0 & 15.6 & 15.1 & 15.1 & 17.1 & 4.6 \\
\hline Sunflower & 68.4 & 73.9 & 64.4 & 70.6 & 70.9 & 69.7 & 71.5 & 64.4 \\
\hline Groundnuts & 8.7 & 15.4 & 3.4 & 11.6 & 16.7 & 9.6 & 9.4 & 15.6 \\
\hline Common beans & 8.3 & $17.9^{\star}$ & 4.7 & 11.0 & 19.4 & 9.4 & 11.5 & 7.7 \\
\hline
\end{tabular}

Note: ${ }^{\star}=$ difference is significant at $\mathrm{P}=0.1 ;{ }^{* \star}=$ difference is significant at $\mathrm{P}=0.05$;

${ }^{\star \star \star}=$ difference is significant at $\mathrm{P}=0.01$

Source: Authors' own

Table 3.13: Overall crop commercialisation indices (per cent) by farmer category

\begin{tabular}{|c|c|c|c|}
\hline Farmer category & Mean & Median & Significance of the effect \\
\hline \multicolumn{2}{|l|}{ Farm size category: } & & \\
\hline SSF & 38.5 & 38.0 & $F=15.989^{\star \star \star}$ \\
\hline MSF & 51.1 & 54.1 & \\
\hline \multicolumn{4}{|c|}{ Sex of household head: } \\
\hline $\mathrm{FHH}$ & 33.4 & 28.5 & $F=5.621^{\star \star}$ \\
\hline $\mathrm{MHH}$ & 41.8 & 41.6 & \\
\hline \multicolumn{4}{|c|}{ Age category of farmer: } \\
\hline Young & 48.2 & 51.0 & $F=10.824^{\star \star \star}$ \\
\hline Old & 38.6 & 37.7 & \\
\hline \multicolumn{4}{|c|}{ Livestock keeping category: } \\
\hline Livestock keepers & 42.2 & 42.7 & $F=3.586^{\star}$ \\
\hline Non-livestock keepers & 37.1 & 30.7 & \\
\hline Whole sample & 59.2 & 65.2 & \\
\hline
\end{tabular}

Note: $F={ }^{*}$; implies $F$ value is significant at $p<0.1 . F={ }^{* * *}$; implies $F$ value is significant at $p<0.01$.

Source: Authors' own 
intermediate outcome of commercialisation with the potential of contributing to food security and poverty reduction but the actual impact of commercialisation on food security and poverty depends on how the income is utilised.

\subsubsection{Sources of household income by farmer category}

Household income comprises crop, livestock and non-farm income. Table 3.14 shows percentages of households that derived income from crops, livestock and non-farm activities in 2017/18. As indicated in Table 3.14, all sampled households derived income from crops irrespective of farmer category. However, the percentage of households deriving income from livestock and non-farm activities varied across farmer categories. The percentage of $\mathrm{MHH}$ and households headed by MSF, old farmers and livestock keepers that derived income from livestock in 2017/18 farming season was higher than $\mathrm{FHH}$ and households headed by SSF, young farmers and non-livestock keepers. On the contrary, non-farm income was more important for $\mathrm{FHH}$ and households headed by MSF, young farmers and non-livestock keepers than their counterparts.

\subsubsection{Food security status across different} categories of farmer

Differences exist in food security status across farmer categories as indicated in Table 3.15. For the whole sample, the percentage of food-secure households was 49 per cent. However, the percentage of $\mathrm{MHH}$ and households headed by MSF, young farmers and livestock keepers that were food secure was significantly higher than those of $\mathrm{FHH}$ and households headed by SSF, old farmers and non-livestock keepers. the percentage of food-secure households also varied significantly by the level of crop commercialisation. As indicated in Table 3.15, the percentage of food-secure households increased from 32 per cent for farmers who did not commercialise ( 0 per cent $\mathrm{RCl}$ ) to 58.4 per cent for rice farmers with a medium commercialisation level and then declined to 53.8 per cent for farmers with a high level of rice commercialisation. The decline in food security is often associated with cultural factors among agropastoralists of keeping large numbers of livestock for prestige and dowry payment (Randolph et al., 2007; Pica-Camara et al., 2011; Thornton et al., 2011; Bahta et al., 2017; Mayala, Katundu and Msuya, 2019). They would rather sell harvested food crops to purchase livestock instead of selling livestock to purchase food.

Table 3.14: Percentage of households by income source and farmer category, 2017/18

\begin{tabular}{|c|c|c|c|}
\hline \multirow[t]{2}{*}{ Farmer category } & \multicolumn{3}{|l|}{ Income source } \\
\hline & Crop income & Livestock income & Non-farm income \\
\hline \multicolumn{4}{|l|}{ Farm size: } \\
\hline SSF & 100.0 & 48.6 & 75.1 \\
\hline MSF & 100.0 & 66.7 & 60.0 \\
\hline \multicolumn{4}{|c|}{ Sex of household head: } \\
\hline $\mathrm{FHH}$ & 100.0 & 35.4 & 80.5 \\
\hline $\mathrm{MHH}$ & 100.0 & 53.9 & 71.1 \\
\hline \multicolumn{4}{|c|}{ Age category of farmer: } \\
\hline Young & 100.0 & 50.8 & 75.0 \\
\hline Old & 100.0 & 51.7 & 71.6 \\
\hline \multicolumn{4}{|c|}{ Livestock keeping category: } \\
\hline Livestock keepers & 100.0 & 58.8 & 68.3 \\
\hline Non-livestock keepers & 100.0 & 35.4 & 82.3 \\
\hline \multicolumn{4}{|c|}{ Crop commercialisation level: } \\
\hline Zero & 100.0 & 50.9 & 73.1 \\
\hline Low & 100.0 & 54.4 & 71.3 \\
\hline Median & 100.0 & 49.7 & 75.2 \\
\hline High & 100.0 & 52.8 & 70.2 \\
\hline Whole sample & 100.0 & 51.4 & 72.4 \\
\hline
\end{tabular}

Source: Authors' own 
It was evident from the focus group discussions that agropastoralists rarely sell livestock because they use livestock as a store and sign of wealth (Isinika and Mwajombe, 2019).

\subsubsection{Household poverty status across different categories of farmer}

Like food security status, the percentage of households with a high level of deprivation (MPI poor) differed across different farmer categories (Table 3.16). The percentage of $\mathrm{MHH}$ and households headed by MSF, livestock keepers that had a high level of deprivation (MPI poor) was significantly lower than those of $\mathrm{FHH}$ and households headed by SSF and non-livestock keepers. The percentage of food secure households headed by old farmers was higher than those headed by young farmers but the difference was not significant. Regarding the level of deprivation across households with different $\mathrm{CCl}$, the percentage of households with low level of deprivation (MPI poor) decreased from 89.1 per cent for farmers who did not commercialise to 22.2 per cent for rice farmers with a medium crop commercialisation level and then increased to 28.8 per cent for farmers with a high level of crop commercialisation (Table 3.16). Like the case of food security discussed above, the decline in poverty can be associated with the same cultural factors. It was evident during the focus group discussions that some agropastoralists who ranked highly in terms of number of cattle-ownership ranked low in terms of quality of housing, clothing and children's education, which area criteria considered important in defining the quality of life in the study area (Isinika and Mwajombe, 2019). Additionally, agropastoralists rarely sell livestock to build modern houses and/or purchase physical assets besides livestock which unfortunately were not among the assets used in the computation of MPI as a measure of poverty in this paper.

\subsection{Econometric results}

\subsubsection{The effect of livestock on crop commercialisation: results of the fractional probit model}

Livestock as an integral part of the farming systems in Singida was hypothesised to have a positive effect on crop commercialisation through the use of animal traction, manure and income from livestock in crop production. Table 3.17 presents the results of the fractional probit regression analysis on the influence of livestock and other factors on crop commercialisation in the Singida region. The model represents a good

Table 3.15: Percentage of households that are food-secure and insecure by farmer category

\begin{tabular}{|c|c|c|c|}
\hline Farmer category & Food-secure & Food insecure & $x^{2}$ \\
\hline \multicolumn{4}{|l|}{ Farm size: } \\
\hline SSF & 42.6 & 57.4 & $37.290^{\star \star \star}$ \\
\hline MSF & 77.1 & 22.9 & \\
\hline \multicolumn{4}{|c|}{ Sex of household head: } \\
\hline $\mathrm{FHH}$ & 31.6 & 68.4 & $10.618^{\star \star \star}$ \\
\hline $\mathrm{MHH}$ & 51.8 & 48.2 & \\
\hline \multicolumn{4}{|l|}{ Age of farmer: } \\
\hline Young & 62.3 & 37.7 & $10.369^{\star \star \star}$ \\
\hline Old & 45.2 & 54.8 & \\
\hline \multicolumn{4}{|c|}{ Livestock keeping category: } \\
\hline Livestock keepers & 52.2 & 47.8 & $5.334^{\star \star}$ \\
\hline Non-livestock keepers & 41.7 & 58.8 & \\
\hline \multicolumn{4}{|c|}{ Crop commercialisation level: } \\
\hline Zero & 32.6 & 67.4 & \\
\hline Low & 46.6 & 53.4 & \\
\hline Median & 58.4 & 41.6 & $16.0^{* *}$ \\
\hline High & 53.2 & 46.8 & \\
\hline Whole sample & 49.0 & 51.0 & \\
\hline
\end{tabular}

Note: $\mathrm{F}={ }^{*}$; implies $\mathrm{F}$ value is significant at $\mathrm{p}<0.1 . \mathrm{F}={ }^{* \star *}$; implies $\mathrm{F}$ value is significant at $\mathrm{p}<0.01$.

Source: Authors' own 
fit for the data based on the log likelihood, pseudo R-Square and corresponding F-value. The number of livestock kept per household was measured using TLU1 which appeared to have a negative effect on crop commercialisation (Table 3.17). The marginal effect of TLU of -0.0002 implies that increasing the livestock herd by one more TLU is likely to reduce crop commercialisation by 0.02 per cent. This likelihood of crop commercialisation reductions stems from the fact that livestock production in the mixed crop-livestock farming system provides a new commercialisation pathway to crop farming. An increasing share of livestock income relative to that from crops would likely suppress the commercialisation tendency for crop based income sources. Factors other than livestock which had a positive effect on crop commercialisation were age category of farmer, education, land planted with crops, use of modern tillage implements such as animal traction and tractors, mobile phones, purchased seeds, inorganic fertilisers, organic fertilisers (livestock manure) and pesticides. Among these factors, age of farmer, land planted with crops and the use of pesticides to control pests had a significant positive effect on crop commercialisation. The remaining factors had an insignificant positive effect on crop commercialisation. Being a young household head had a higher marginal effect than the other factors with a positive influence on rice commercialisation. The marginal effect of 0.116 for youth indicates that the level of crop commercialisation is likely to increase by approximately 12 per cent for an additional household head by a young farmer compared with an increase of about 3 per cent for an additional ha of land planted with crops. This suggests significant gains in crop commercialisation if a household is headed by a young farmer instead of an old farmer. This finding is consistent with the results of previous studies that young farmers are more commercially oriented than old farmers (Khapayi and Celliers, 2016; Hall, Scoones and Tsikata, 2017; Liu, Bruins and Heberling, 2018; Mariyono, 2019).

Factors with negative effects on crop commercialisation included household size, non-farm income and distance to nearest road, however these effects were insignificant. The negative coefficient for household size indicates that the crop commercialisation level

Table 3.16: Percentage of households by poverty level (MPI) and farmer category

\begin{tabular}{|c|c|c|c|}
\hline Farmer category & $\begin{array}{l}\text { MPI poor (high level of } \\
\text { deprivation) }\end{array}$ & $\begin{array}{l}\text { MPI not poor (low level of } \\
\text { deprivation) }\end{array}$ & $x^{2}$ \\
\hline \multicolumn{4}{|l|}{ Farm size category: } \\
\hline SSF & 79.7 & 20.3 & $14.672^{\star \star \star}$ \\
\hline MSF & 59.5 & 40.5 & \\
\hline \multicolumn{4}{|c|}{ Sex of household head: } \\
\hline $\mathrm{FHH}$ & 78.6 & 21.4 & $18.307^{\star \star \star}$ \\
\hline $\mathrm{MHH}$ & 24.9 & 75.1 & \\
\hline \multicolumn{4}{|c|}{ Age category of farmer: } \\
\hline Young & 69.9 & 30.1 & $1.569 \mathrm{~ns}$ \\
\hline Old & 76.8 & 23.2 & \\
\hline \multicolumn{4}{|c|}{ Livestock keeping category: } \\
\hline Livestock keepers & 75.6 & 26.5 & $2.695^{\star}$ \\
\hline Non-livestock keepers & 81.6 & 18.4 & \\
\hline \multicolumn{4}{|c|}{ Crop commercialisation level: } \\
\hline Zero & 89.1 & 10.9 & $9.1^{\star \star}$ \\
\hline Low & 28.9 & 71.1 & \\
\hline Median & 22.2 & 77.8 & \\
\hline High & 28.8 & 71.2 & \\
\hline Whole sample & 24.2 & 75.8 & \\
\hline
\end{tabular}

Note: $F={ }^{*}$; implies $F$ value is significant at $p<0.1 . F={ }^{* \star *}$; implies $F$ value is significant at $p<0.01$.

Source: Authors' own

$1 \quad$ Tropical Livestock Unit (TLU) is defined as a mature animal weighing an average weight of $175 \mathrm{~kg}$ (Jahnke, 1982). Livestock conversion factors are 0.70 TLU for cattle, 01 TLU for goats and sheep, 0.2 for pigs and 0.01 for chickens. 
declines with increase in the household size. The marginal effect of household size of -0.0103 implies that increasing the household size by one more person is likely to decrease crop commercialisation by 1.03 per cent (Table 3.17). Increase in household size reduces marketable surplus due to increase in household consumption (Demeke and Haji, 2014; Owagbemi et al., 2016; Turaa et al., 2016; Kyaw, Ahn and Lee, 2018). The negative coefficient for distance to nearest motorable road as a proxy of market access suggests that crop farmers close to a motorable road will likely be more commercialised than farmers in remote areas. Improvement in market access is an incentive for farmers to increase agricultural productivity and hence increase in marketable surplus (Ingabire et al., 2017; Aku et al., 2018; Linderhof, Janssen and Achterbosch, 2019; Ntakyo and van den Berg, 2019; Ogutu, Gödecke and Qaim, 2020).

\subsubsection{The effect of livestock on household poverty: results of the probit model}

Table 3.18 presents the estimates of the effects of livestock and other factors on household poverty measured in terms of MPI as indicated in the methodology. As indicated in Table 3.18, the number of livestock measured in terms of TLU is negatively related to the MPI as expected, implying that livestock in crop-livestock farming systems of the Singida region increases the probability of reducing poverty among crop-producing households. This result is consistent with the findings by Sarkar (2020); Hegde (2019); Rabby, Fredericks and Alam (2013) and Alary, Corniaux and Gautier (2011).

Factors other than livestock found to have a significant effect on MPI included education, non-farm income and the second crop commercialisation tercile $\left(\mathrm{CCl}_{-}\right.$ T2). The coefficient for education of household head was negative, suggesting a high likelihood of decline in poverty in a household as the education level of the household head increases. The decline in poverty with increase in education is associated with improvement of agricultural productivity resulting from better understanding of improved farming practices among educated farmers (Rahman, 2013; Maiyo, 2015; Wanka and Rena, 2019; Mdoe et al., 2020). As expected, nonfarm income had a significant negative effect on MPI. The negative effect on MPI suggests the likelihood of reducing household poverty as the household earns more non-farm income. The role of non-farm income in reducing household poverty in rural area is widely reported (see for example Anríquez and Stamoulis, 2007; Mata, Jalilb and Harun, 2012; Rantšo, 2014; Alobo-Loison, 2015; Idris and Siwar, 2017). The effect of crop commercialisation was determined using dummy variables assigned to the terciles. The first tercile

Table 3.17: Determinants of crop commercialisation in the Singida region: results of the fractional probit regression $(\mathrm{CCl} \leq 1)$

\begin{tabular}{|l|l|l|l|l|}
\hline Independent variable & Coefficient & Robust se & Marginal effect & $p>|z|$ \\
\hline Sex category of household head (1 = male head) & 0.0009 & 0.1399 & -0.0003 & 0.995 \\
\hline Age category of farmer (1 = young farmer) & $0.2946^{\star \star \star}$ & 0.1003 & 0.1157 & 0.003 \\
\hline Education (years of schooling) & 0.0223 & 0.0182 & 0.0088 & 0.220 \\
\hline Household size & -0.0253 & 0.0160 & -0.0099 & 0.114 \\
\hline Total land planted with crops (ha) & $0.0726^{\star \star \star}$ & 0.0165 & 0.0285 & 0.000 \\
\hline Number of livestock kept (TLU) & -0.0005 & 0.0069 & -0.0002 & 0.933 \\
\hline Use of modern tillage implement (1=yes) & 0.0195 & 0.0755 & 0.0076 & 0.796 \\
\hline Use of mobile phone (1=yes) & 0.0247 & 0.1013 & 0.0097 & 0.807 \\
\hline Use of purchased seed (1 = yes) & 0.0904 & 0.1058 & 0.0355 & 0.393 \\
\hline Use of inorganic fertiliser (1 =yes) & 0.1318 & 0.1143 & 0.0518 & 0.249 \\
\hline Use of organic fertiliser (1 =yes) & 0.0014 & 0.0791 & 0.0006 & 0.986 \\
\hline Use of pesticide (1 = yes) & $0.1941^{\star}$ & 0.1075 & 0.0762 & 0.071 \\
\hline Non-farm income (100,000 Tsh) & -0.0061 & 0.0040 & -0.0024 & 0.127 \\
\hline Distance to nearest road & -0.0111 & 0.0118 & -0.0043 & 0.351 \\
\hline Constant & $-0.5595^{\star \star \star}$ & 0.1888 & & 0.003 \\
\hline
\end{tabular}

$\mathrm{N}=354$, Wald $\chi_{(15)}^{2}=54.67, \mathrm{p}>\chi^{2}=0.000$ and Pseudo $\mathrm{R} 2=0.0345$

Notes: * significant at $\mathrm{p}<0.1{ }^{\star \star}$ significant at $\mathrm{p}<0.05$ and ${ }^{\star \star \star}$ significant atp $<0.01$

Source: Authors' own 
was used as a base. As indicated in Table 3.18, the coefficients of both the second and third tercile had the expected negative sign but only the coefficient of the second tercile was significant. The negative coefficients suggest that crop commercialisation is likely to reduce household poverty as reported by several studies on the effect of agricultural commercialisation on poverty (See for example Hailua, Manjure and Aymutc, 2015; Muriithi and Matz, 2015; Ochieng and Hepelwa, 2018; Cazzuffi, McKay and Perge, 2020; Isinika et al., 2020; Mdoe et al., 2020).

Coefficients for sex of household head, age category of the farmer, household size and total cropland are insignificant. Regarding the sex of household head, being a male had a significant positive effect on MPI. The positive effect on MPI suggests a high likelihood of an $\mathrm{MHH}$ being poor. This result supports the finding by Majeed and Malik (2015) but contradicts the findings that $\mathrm{FHH}$ are likely to be more impoverished than $\mathrm{MHH}$ (Buvinic, Gupta and Casabonne, 2009; Mitiku, 2014; Isinika et al., 2020; Mdoe et al., 2020). The coefficient of age category is negative, suggesting that households headed by young farmers are more likely to be less poor than households headed by old farmers. This result supports similar findings from numerous studies that show households are likely to be poor as the age of the household head increases (Rahman, 2013; Isinika et al., 2020; Mdoe et al., 2020).

As in the case of the sex of household head, household size had a positive effect on MPI, suggesting that household poverty is likely to increase as the household size increases because of a higher dependency ratio, as reported by previous studies that have examined the effect of household size on household poverty (see for example Meyer and Nishimwe-Niyimbanira, 2016; Isinika et al., 2020; Mdoe et al., 2020). As expected, total cropland had a negative effect on MPI, implying the likelihood of reducing household poverty as total cropland increases. This finding is consistent with results of previous studies that have examined the effect of farm size on poverty that household poverty is likely to decline as the farm size increases (Ogwumike and Akinnibosun, 2013; Gassner et al., 2019; Mdoe et al., 2020; Olarinde et al., 2020; Onuche and Oladipo, 2021).

Table 3.18: Determinants of household poverty status: probit estimates

\begin{tabular}{|l|l|l|l|l|}
\hline Independent variable & Coefficient & Roloust se & Marginal effect & $p>|z|$ \\
\hline Sex category of household head (1 = male head) & 0.2655 & 0.2334 & 0.0842 & 0.255 \\
\hline Age category of farmer (1 = young farmer) & -0.2847 & 0.1883 & -0.0903 & 0.131 \\
\hline Education (years of schooling) & $-0.0693^{\star}$ & 0.0386 & -0.0219 & 0.072 \\
\hline Household size & 0.0105 & 0.0309 & 0.0033 & 0.735 \\
\hline Total crop land (ha) & -0.0414 & 0.0333 & -0.0131 & 0.214 \\
\hline Number of livestock kept (TLU)) & $-0.029^{\star \star} 6$ & 0.0139 & -0.0094 & 0.034 \\
\hline Non-farm income (100,000Tsh) & $-0.0296^{\star \star}$ & 0.00937 & -0.00643 & 0.031 \\
\hline CCl_T 2 & $-0.3910^{\star \star}$ & 0.1945 & -0.1239 & 0.044 \\
\hline CCl_T3 & -0.1306 & 0.1921 & -0.439 & 0.497 \\
\hline Constant & $1.4069^{\star \star \star}$ & 0.3319 & & 0.000 \\
\hline
\end{tabular}

$\mathrm{N}=357$, Wald $\chi^{2}(9)=31.91, \mathrm{p}>\chi^{2}=0.0002$ and Pseudo $\mathrm{R} 2=0.0917$

Notes: * significant at $\mathrm{p}<0.1,{ }^{* \star}$ significant at $\mathrm{p}<0.05$ and ${ }^{* \star *}$ significant at $\mathrm{p}<0.01$

Source: Authors' own 
This paper examined the effect of livestock on crop commercialisation and farmers' livelihoods in the Singida region, Tanzania. Quantitative data for the analysis were extracted from the APRA data set of 600 households selected randomly from random samples of eight and seven villages in Iramba and Mkalama districts respectively. The quantitative data were complemented with qualitative data collected through focus group discussions and key informant interviews. The results show that livestock has enhanced crop commercialisation rather than inhibiting it. This enhancement stems from the provision of livestock manure for soil fertility improvement and animal traction as a tillage technology. The complementarity between crop and livestock in the farming systems of Singida need to be recognised, enhanced and employed not only by farmers and livestock keepers but also by local government authorities and development practitioners. Specifically, the following activities need to be carried out: (i) promote use of manure for fertility improvement, (ii) promote use of animal power not only for land preparation but also for weeding and transportation of harvested crops to homesteads/warehouses/market and, (iii) promote use of crop residues and by-products from crop farms as livestock feed. This should go hand in hand with encouraging livestock keepers to control livestock numbers to avoid land degradation.

Apart from livestock, a range of other factors have worked together with livestock to drive the crop commercialisation process. These include use of tractor as a tillage implement, total land planted with crops, farmer's education level, access to markets and the use of productivity (yield) enhancing inputs such as improved seed, inorganic fertilisers and pesticides. Tractors can be promoted as an option for farmers who find them more beneficial than animal power through the establishment of tractor hire services where farmers can access tractor services at an affordable cost. The full benefits from tractors can be derived if they are used for tillage, transportation and shelling. The promotion of animal traction and tractors for tillage should go hand in hand with ensuring timely availability and application of fertilisers to complement the use of manure to enhance crop yields.
Meanwhile, some factors were obstacles to crop commercialisation which, if addressed, could accelerate the crop commercialisation processes. These include but are not limited to household size - which increases subsistence consumption at the expense of marketable surplus - and poor access to crop markets due to the absence of good roads that link the crop producing villages to crop markets. Interventions to promote crop commercialisation should go hand in hand with efforts to increase access to family planning and reproductive health services in rural areas. This will address the decline in marketable surplus due to high household consumption in big households and hence reduce marketable surplus. Regarding market access, the government has made commendable improvements in major roads connecting regional and district headquarters in the country through TANROADS. Although the government has established TARURA, much remains to be done to improve and maintain roads connecting district headquarters to villages. TARURA should be given annual budget allocation by the central government. This should be complemented by funds from respective district councils when needs arise.

While commercialisation has been seen as a linear process, whereby farming households specialise as they climb the ladder of commercialisation, evidence from our study shows that commercialisation has gone hand in hand with diversification within and outside the crop sub-sector. Reasons behind this tendency may include aversion to risks that could arise from relying on a single enterprise desire to exploit a diversified demand for produce; and the importance for many small farmers of continuing to produce a large share of staples, such as cereals and legumes, for home consumption. This calls for government and development partners efforts to promote enterprise diversity instead of the idea of "one district one crop", which is essentially promoting specialisation.

Regarding the impacts of commercialisation, the results show that farmers have gained higher productivity (yield) and income levels through commercialised crops, signifying the potential of crop commercialisation to improve food security and reduce income poverty. The 
actual impact of commercialisation on food security and poverty depends on how the income is utilised. In general, the results of our study show improvement in household food security and reduction in poverty as crop commercialisation increases from zero to medium level. However, household food security slightly declines and poverty levels slightly increase as crop commercialisation increases from medium to high level.

Although crop commercialisation has positively impacted on crop productivity (yields), household incomes, food security and poverty, the results of our study show that some socioeconomic disparities exist. $\mathrm{MHH}$, households headed by MSF, households headed by young farmers and households with livestock fared well in terms of level of commercialisation, food security and poverty reduction, being above their counterparts, including $\mathrm{FHH}$, households headed by SSF, households headed by old farmers and households without livestock. These social differences are the consequences of differential access to land, use of modern tillage implements and the use of productivity enhancing inputs. For example, $\mathrm{MHH}$ had more access to land for commercial crop production compared to their $\mathrm{FHH}$ counterparts while households headed by MSF had more access to land than households headed by SSF. In addition to more access to land, use of modern tillage implements and productivity enhancing inputs was higher among $\mathrm{MHH}$ and households headed by MSF than $\mathrm{FHH}$ and households headed by SSF. Diversifying agriculture and livestock with non-farm incomes sources, particularly wage income from seasonal work and transfers, appears to be more important for the livelihoods of resource poor farmers (female and small-scale) than their counterparts (male and medium- or large-scale). The mechanism of combining overlapping livelihood activities in the process of improving livelihoods of households in Singida, a semi-arid region, needs to be recognised. It is insufficient to assume that government efforts that raise crop and livestock outputs would help SSF and $\mathrm{FHH}$. These farmer categories need to be recognised as having the least access to land, and thus efforts directed at raising crop and livestock productivity will benefit the already better-off more than the poor. This in turn will further widen the existing social differentiation. Promoting non-farm activities alongside crop and livestock activities as the way forward in improving the livelihoods of resource-poor and female farmers. 
Akresh, R. (2005) Understanding Pareto Inefficient Intra-household Allocations. IZA Discussion Paper No. 1858. Bonn: Institute for the Study of Labor. Available at: https://ssrn.com/abstract=866885 (Accessed: 16 April 2021).

Aku, A., Mshenga, P., Afari-Sefa, V. and Ochieng, J. (2018) 'Effect of Market Access Provided by Farmer Organizations on Smallholder Vegetable Farmer's Income in Tanzania', Cogent Food and Agriculture, 4:1, 1560596. Available at: https://doi.org/10.1080/23311932.2018.1560596 (Accessed: 12 April 2021).

Alary, V., Corniaux, C. and Gautier, D. (2011) 'Livestock's Contribution to Poverty Alleviation: How to Measure It?', World Development 39.9: 1638-1648. Available at: https://ideas.repec.org/a/eee/wdevel/v39y2011i9p1638-1648. html (Accessed: 25 March 2021).

Alawode, O.O., Abegunde, V.O. and Abdullahi, A.O. (2018) 'Rural Land Market and Commercialization among Crop Farming Households in Southwestern Nigeria', International Journal of Innovative Food, Nutrition and Sustainable Agriculture, 6.3: 54-62. Available at: https://seahipaj.org/journals-ci/sept-2018/IJIFNSA/full/IJIFNSA-S-6-2018. pdf (Accessed: 11 April 2021).

Alkire, S., Roche, J.M. and Vaz, A. (2015) 'Changes Over Time in Multidimensional Poverty: Methodology and Results for 34 Countries', Working Paper 76, Oxford Poverty and Human Development Initiative (OPHI), 94(76). Available at: http://dx.doi.org/10.1016/j.worlddev.2017.01.011 (Accessed: 21 March 2021).

Alkire, S. and Santos, M.E. (2014) 'Measuring Acute Poverty in the Developing World: Robustness and Scope of the Multidimensional Poverty Index', World Development 59: 251-74. Available at: https://www.sciencedirect. com/science/article/abs/pii/S0305750X14000278 (Accessed: 12 April 2021).

Alobo-Loison, S. (2015) 'Rural Livelihood Diversification in Sub-Saharan Africa: A Literature Review', The Journal of Development Studies 51(9): 1125-38. Available at: https://www.tandfonline.com/doi/full/10.1080/00220388.20 15.1046445 (Accessed: 15 April 2021).

Amejo, A. and Habtemariam, K. (2018) 'Agricultural Productivity, Land Use and Draught Animal Power Formula Derived from Mixed Crop-Livestock Systems in South-western Ethiopia', African Journal of Agricultural Research 13(42): 2362-2381. Available at: https://www.cifor.org/knowledge/publication/5788 (Accessed: 21 March 2021).

Anderson, C.L., Reynolds, T., Merfeld, J.D and Biscaye, P. (2016) 'Relating Seasonal Hunger and Prevention and Coping Strategies: A Panel Analysis of Malawian Farm Households', The Journal of Development Studies 57(4): 1737-1755. Available at: https://epar.evans.uw.edu/research/seasonal-hunger-and-coping-and-preventionstrategies-malawi (Accessed: 12 April 2021).

Anríquez, G and Stamoulis, K (2007) 'Rural Development and Poverty Reduction: Is Agriculture Still the Key?', Journal of Agricultural and Development Economics 4(1): 5-46. Available at: https://ideas.repec.org/p/fao/ wpaper/0702.html (Accessed: 12 April 2021).

Bahta, S., Wanyoike, F., Katjiuongua, H. and Marumo, D. (2017) 'Characterisation of Food Security and Consumption Patterns among Smallholder Livestock Farmers in Botswana', Agriculture and Food Security 6: 65. Available at: https://doi.org/10.1186/s40066-017-0145-1 (Accessed: March 31 2021).

Bates, R. (1981) Markets and States in Tropical Africa, Berkeley: University of California Press.

Bekele, A. and Alemu, D. (2015) 'Farm-Level Determinants of Output Commercialization: In Haricot Bean Based Farming Systems', Ethiopian Journal of Agricultural Sciences 25(1): 61-69. Available at: https://www.ajol.info/ index.php/ejas/article/view/142999 (Accessed 12 April 2021). 
Blackmorea, I., Rivera, C, Waters, W.F, lannotti, L. and Lesorogo, C. (2021) 'The Impact of Seasonality and Climate Variability on Livelihood Security in the Ecuadorian Andes', Climate Risk Management 32. Available at: https://doi.org/10.1016/j.crm.2021.100279 (Accessed 26 March 2021).

Buvinic, M; Gupta, M.D and Casabonne, U (2009) 'Gender, Poverty and Demography: An Overview', The World Bank Economic Review 23(3): 347-369.

Cazzuffi, C; McKay, A and Perge, E (2020) 'The Impact of Agricultural Commercialisation on Household Welfare in Rural Vietnam', Food Policy, Elsevier, Vol. 94(C). Available at: https://doi.org/10.1016/j.foodpol.2019.101811 (Accessed: 15 April 2021).

Challa, M. T., and Mahendran, A. (2015). 'Gender difference and its impact on agricultural productivity: The case of Sheko District in Bench Maji Zone of SNNP, Ethiopia', International Journal of Current Research 7(11): 22938-22942.

Croppenstedt, A., Goldstein, M. and Rosas, N. (2013). 'Gender and Agriculture: Inefficiencies, Segregation, and Low Productivity Traps', The World Bank Research Observer, 28(1): 79-109.

Demeke, L.B. and Haji, J. (2014) 'Econometric Analysis of Factors Affecting Market Participation of smallholder Farming in Central Ethiopia', Journal of Agricultural Economics, Extension and Rural Development 2(6): 094-104.

Dube, L and Guveya, E. (2016) 'Determinants of Agriculture Commercialization among Smallholder Farmers in Manicaland and Masvingo Provinces of Zimbabwe', Agricultural Science Research Journal 6(8): 182-90.

Engida, E; Guthiga, P. and Karugia, J. (2015) The Role of Livestock in the Tanzanian Economy: Policy Analysis Using a Dynamic Computable General Equilibrium Model for Tanzania, 2015 Conference, August 9-14, 2015, Milan, Italy 212039, International Association of Agricultural Economists. Available at: https://ideas.repec.org/p/ ags/iaae15/212039.html (Accessed 16 April 2021).

Fischer, E and Qaim, M (2012) 'Gender, Agricultural Commercialization, and Collective Action in Kenya', Food Security 4: 441-453.

Fountas, S., Wulfsohn, D., Blackmore, B.S., Jacobsen, H.L. and Pedersen, S.M. (2006) 'A Model of Decisionmaking and Information Flows for Information-Intensive Agriculture', Agricultural Systems 87(2): 192-210.

Gassner, A., Harris, D., Mausch, K. and Terheggen, A. (2019) 'Poverty Eradication and Food Security through Agriculture in Africa: Rethinking Objectives and Entry Points', Outlook on Agriculture 48(4): 309-315.

Gautam, Y and Andersen P. (2016) 'Rural Livelihood Diversification and Household Well-being: Insights from Humla, Nepal', Journal of Rural Studies 44: 239-249.

Gautam, Y., and Andersen, P. (2017) 'Multiple Stressors, Food System Vulnerability and Food Insecurity in Humla, Nepal', Regional Environmental Change 17: 1493-1504.

Gebre, G.G., Isoda, H., Rahut, D.B., Amekawa, Y. and Nomura, H. (2021). 'Gender differences in agricultural productivity: evidence from maize farm households in southern Ethiopia', Geo Journal 86: 843-864.

Gebremariam, G. and Wünsher, T. (2016) Combining Sustainable Agricultural Practices Pays Off: Evidence on Welfare Effects from Northern Ghana, Paper Presented at the Fifth International Conference of the Association of Agricultural Economists (AAAE), Addis Ababa, 23-26 September.

Gebremedhin, B. and Jaleta, M. (2010) Commercialization of Smallholders: Does Market Orientation Translate into Market Participation? Improving Productivity and Market Success (IPMS) of Ethiopian Farmers, Project Working Paper 22, Nairobi: ILRI. Available at: https://hdl.handle.net/10568/3015 (Accessed: 15 March 2021).

Gupta, S., Vemireddy, V. and Pingali, P.L. (2019) 'Nutritional Outcomes of Empowerment and Market Integration for Women in Rural India', Food Security 11(6): 1243-56.

Hagos, A. and Geta, E. (2016) 'Review on Smallholders Agriculture Commercialization in Ethiopia: What are the Driving Factors to Focuse on?', Journal of Development and Agricultural Economics 8(4): 65-76. 
Hailua, G., Manjure, K. and Aymutc, K. (2015) 'Crop Commercialization and Smallholder Farmers' Livelihood in Tigray Region, Ethiopia', Journal of Development and Agricultural Economics 7(9): 314-322.

Hall, R., Scoones, I. and Tsikata, D. (2017) 'Plantations, Out-growers and Commercial Farming in Africa: Agricultural Commercialisation and Implications for Agrarian Change', Journal of Peasant Studies 44(3): 515-537.

Hegde, N.G. (2019) 'Livestock Development for Sustainable Livelihood of Small Farmers', Asian Journal of Research in Animal and Veterinary Sciences 3(2): 1-17.

Heyer, J., Roberts, P. and Williams, G. (eds.) (1981). Rural Development in Tropical Africa. London: Macmillan.

Idris, N.D.M and Siwar, C. (2017) 'From Poverty Reduction to Poverty Relief: Impact of Non-farm Income in Integrated Agriculture Development Area (IADA) Samarahan, Sarawak, Malaysia', Malaysian Journal of Society and Space 11(1): 32-41.

Isinika, A., Mlay, G, Boniface, G., Mdoe, N., Poulton, C. and Saha, A. (2020). Does Rice Commercialisation Impact on Livelihood? Experience from Mngeta in Kilombero District, Tanzania, APRA Working Paper 30, Brighton: Future Agricultures. Available at: https:/www.future-agricultures.org/publications/working-papers-document/ working-paper-30-does-rice-commercialisation-impact-on-livelihood-experience-from-mngeta-in-kilomberodistricttanzania/ (Accessed: 28 April 2021).

Isinika, A.C. and Mwajombe, K. (2019) ‘Qualitative Report. APRA Tanzania: Work Stream 2 (WS2), Unpublished Research Report.

Jahnke, H.E. (1982) Livestock Production Systems and Livestock Development in Tropical Africa. Kiel Germany: Keiler Wissenschaftsverlag Vauk.

Jones, P.G. and Thornton, P.K. (2009) 'Croppers to Livestock Keepers: Livelihood Transitions to 2050 in Africa due to Climate Change', Environmental Science and Policy 12: 427-37.

Khapayi M., and Celliers P.R. (2016) 'Factors Limiting and Preventing Emerging Farmers to Progress to Commercial Agricultural Farming in the King William's Town Area of the Eastern Cape Province, South Africa', South Africa Journal of Agricultural Extension 44. Available at: http://dx.doi.org/10.17159/2413-3221/2016/ v44n1a374 (Accessed: 21 April 2021).

Kibiti, H.M., Raidimi, N.E., Pfumayaramba, T.K. and Chauke, P.K. (2016) 'Determinants of Agricultural Commercialization among Smallholder Farmers in Munyati Resettlement Area, Chikomba District, Zimbabwe', Journal of Human Ecology 53(1): 10-19.

Kyaw, N., Ahn, S. and Lee, S.H. (2018) 'Analysis of the Factors Influencing Market Participation among Smallholder Rice Farmers in Magway Region, Central Dry Zone of Myanmar', Sustainability 2018, 10(12): 4441. Available at: https://doi.org/10.3390/su10124441 (Accessed: 21 April 2021).

Leavy, J. and Poulton, C. (2007). Commercialisations in Agriculture, FAC Working Paper 03, Brighton: Future Agricultures Consortium. Available at: https://opendocs.ids.ac.uk/opendocs/handle/20.500.12413/2345

(Accessed: 19 April 2021).

Lema M.A. and Majule A.E. (2009) 'Impacts of Climate Change, Variability and Adaptation Strategies on Agriculture in Semi-arid Areas of Tanzania: The Case of Manyoni District in Singida Region, Tanzania', African Journal of Environmental Science and Technology 3(8): 206-218.

Lerman, Z. (2004) 'Policies and Institutions for Commercialization of Subsistence Farms in Transition Countries', Journal Asian Economics 15(3): 461-479.

Linderhof, V., Janssen, V. and Achterbosch, T. (2019) 'Does Agricultural Commercialization Affect Food Security: The Case of Crop-Producing Households in the Regions of Post-Reform Vietnam', Sustainability 11(5): 1263. Available at: https://doi.org/10.3390/su11051263 (Accessed: 18 April 2021).

Liu, T., Bruins, R.J.F and Heberling, M.T. (2018) 'Factors Influencing Farmers' Adoption of Best Management Practices: A Review and Synthesis', Sustainability 10(2). Available at: https://doi.org/10.3390/su10020432 (Accessed: 15 April 2021). 
Maiyo, J. (2015) 'Education and Poverty Correlates: A Case of Trans-Nzoia County, Kenya', International Journal of Educational Administration and Policy Studies 7(7): 142-148.

Majeed, M.T. and Malik, M.N. (2015) ‘Determinants of Household Poverty: Empirical Evidence from Pakistan', The Pakistan Development Review 54(4): 707-717.

Mariyono, J. (2019) 'Stepping up from Subsistence to Commercial Intensive Farming to Enhance Welfare of Farmer Households in Indonesia', Asia and the Pacific Policy Studies 6: 246-265.

Masterson, T. (2007) Female Land Rights, Crop Specialization, and Productivity in Paraguayan Agriculture, Levy Economics Institute Working Paper No. 504. Available at: http://dx.doi.org/10.2139/ssrn.998600 (Accessed: 14 April 2021).

Mata, S.H.C., Jalilb, A.Z.A and Harun, M. (2012) 'Does Non-Farm Income Improve the Poverty and Income Inequality Among Agricultural Household in Rural Kedah?', Procedia Economics and Finance 1: 269-275.

Matenga, C.R. and Hichaambwa, M. (2017) 'Impacts of Land and Agricultural Commercialisation on Local Livelihoods in Zambia: Evidence from Three Models', Journal of Peasant Studies 44(4): 1-20.

Mayala, N.M., Katundu, M.A. and Msuya, E.E. (2019) 'Socio-cultural Factors Influencing Livestock Investment Decisions among Smallholder Farmers in Mbulu and Bariadi Districts, Tanzania', Global Business Review 20(5): $1214-1230$.

Mdoe, N., Boniface, G., Isinika, A., Magomba, C. and Mlay, G. (2020) Effect of Choice of Tillage Technology on Commercialisation and Livelihood of Smallholder Rice Farmers in Mngeta Division, Kilombero District, Tanzania, APRA Working Paper 37, Brighton: Future Agricultures Consortium. Available at: https://opendocs.ids.ac.uk/ opendocs/handle/20.500.12413/15664 (Accessed 28 April 2021).

Meyer, D. and Nishimwe-Niyimbanira, R. (2016) 'The Impact of Household Size on Poverty: An Analysis of Various Low-income Townships in the Northern Free State Region, South Africa', African Population Studies 30(2): 2283-2295.

Mitiku, A. (2014). 'Impact of Smallholder Farmers Agricultural Commercialization on Rural Households' Poverty', The International Journal of Applied Economics and Finance 8: 51-61.

Mkonda, M.Y. and He, X. (2018) 'Climate Variability and Crop Yields Synergies in Tanzania's Semiarid Agro Ecological Zone', Ecosystem Health and Sustainability 4(3): 59-72.

Ingabire, C., Mshenga M.P, Langat, K., Bigler, C., Musoni, A., Butare, L. and Birachi, E. (2017) 'Towards Commercial Agriculture in Rwanda: Understanding the Determinants of Market Participation Among Smallholder Bean Farmers', African Journal of Food, Agriculture, Nutrition and Development 17(4): 12492-12508 .

Muriithi, B.W. and Matz, J.A. (2015) 'Welfare Effects of Vegetable Commercialization: Evidence from Smallholder Producers in Kenya', Food Policy 50: 80-91.

Mutabazi, K., Wiggins, S. and Mdoe, N. (2013) Commercialisation of African Smallholder Farming: The Case of Small Farmers in Central Tanzania, FAC Working Paper 72, Brighton: Future Agricultures Consortium. Available at: https://assets.publishing.service.gov.uk/media/57a08a19e5274a31e0000416/FAC_Working_Paper_072.pdf (Accessed: 29 March 2021)

National Bureau of Statistics (NBS) and Singida regional Secretariat (2017) Singida socio-economic profile, 2015. Ministry of Finance, Dar-Es-Salaam.

Ntakyo, P.R. and van den Berg, M. (2019) 'Effect of Market Production on Rural Household Food Consumption: Evidence from Uganda', Food Security 11: 1051-1070.

Ochieng, N. and Hepelwa, A. (2018) 'Effects of Small-Scale Agricultural Crop Commercialisation on Rural Household Welfare in Tanzania: A Case Study of Liwale District, Lindi Region', International Journal of Agricultural Economics 3(5): 103-111.

Ogunniyi, L.T. and Ajao, A.O. (2010). 'Gender and cost efficiency in maize production in Oyostate of Nigeria', Tropical and Subtropical Agro-ecosystems 12(2): 333-338. 
Ogunleye, G.O., Fashoto, S.G., Mashwama, P., Arekete, S.A., Olaniyan, O.M. and Omodunbi, B.A. (2018) 'Fuzzy Logistic Tool to Forecast Soil Fertility in Nigeria', The Scientific World Journal 1-8. Available at: https://doi. org/10.1155/2018/3170816 (Accessed: 25 March 2021).

Ogutu, S.O., Godecke, T. and Qaim, M. (2020) 'Agricultural Commercialisation and Nutrition in Smallholder Farm Households', Journal of Agricultural Economics 71(2): 534-555.

Ogwumike, F.O. and Akinnibosun, M.K. (2013) 'Determinants of Poverty among Farming Households in Nigeria, Mediterranean', Journal of Social Sciences 4.2 Doi: 10.5901/mjss.2013.v4n2p365 (Accessed: 30 March 2021).

Olarinde, O. (2020) 'Estimating Multidimensional Poverty among Cassava Producers in Nigeria: Patterns and Socioeconomic Determinants', Sustainability 12.13: 5366. Available at: https://doi.org/10.3390/su12135366 (Accessed: 30 March 2021).

Onuche, U. and Oladipo, M.A. (2021). 'Effect of Farm Level Economic Efficiency on Income Poverty Status of Rural Farm Households in Kogi State, Central Nigeria', African Journal of Science, Technology, Innovation and Development 13(1):61-68.

Opiyo, F., Wasonga, O., Nyangito, M., Schilling, J. and Munang, R. (2015) 'Drought Adaptation and Coping Strategies among the Turkana Pastoralists of Northern Kenya', International Journal of Disaster Risk Science 6: 295-309.

Oseni, G., Corral, P., Goldstein, M. and Winters, P. (2015). 'Explaining gender differentials in agricultural production in Nigeria', Agricultural Economics 46(3): 285-310.

Owagbemi T.S., Oluwalana E.O., Sanusi, R.A. and Suleman M. (2016) 'Marketable Surplus and Farm Households Poverty Status in Lagos State', Ife Journal of Agriculture 28(2): 59-73.

Oya, C. (2011) 'Contract Farming in Sub-Saharan Africa: A Survey of Approaches, Debates and Issues', Journal of Agrarian Change 12(1): 1-33. Available at: https://doi.org/10.1111/j.1471-0366.2011.00337 (Accessed: 15 April 2021).

Peterman, A., Quisumbing, A., Behrman, J. and Nkonya, E. (2011). 'Understanding the Complexities Surrounding Gender Differences in Agricultural Productivity in Nigeria and Uganda', Journal of Development Studies 47(10): 1482-1509.

Pica-Camara, U., Tasciotti, L., Otte, J. and Zezza, A. (2011). Livestock Assets, Livestock Income and Rural Households: Cross Country Evidence from Household Surveys. Joint paper of the World Bank, FAO, AU-IBAR and ILRI.

Pingali, P., Aiyar, A., Abraham, M. and Rahman, A. (2019) 'Enabling Smallholder Prosperity Through Commercialization and Diversification', in P. Pingali et al., Transforming Food Systems for a Rising India, Palgrave Studies in Agricultural Economics and Food Policy, Cham: Palgrave Macmillan.

Pingali, P.L (2001) 'Environmental Consequences of Agricultural Commercialization in Asia', Environment and Development Economics 6(4): 483-502.

Rabby, T.G., Fredericks, L.J. and Alam, G.M. (2013) 'Livestock Husbandry Strategy in Alleviating Poverty in the Haor Area of Bangladesh', Asian Journal of Animal and Veterinary Advances, 8: 41-52.

Rahman, M.A. (2013) 'Household Characteristics and Poverty: A Logistic Regression Analysis', The Journal of Developing Areas 47(1): 303-317.

Rahut, D., Castellanos, I.V. and Sahoo, P. (2010) Commercialization of Agriculture in the Himalayas, Discussion Paper No. 265, Chiba: Institute of Developing Economies (IDE).

Randolph, T. F., Schelling, E., Grace, D., Nicholson, C.F., Leroy, J.L., Cole, D.C., Demment, M.W., Omore, A., Zinsstag, J. and Ruel, M. (2007) 'Invited Review: Role of Livestock in Human Nutrition and Health for Poverty Reduction in Developing Countries', Journal of Animal Science 85: 2788-2800.

Rantšo, T.A. (2014) 'The role of the Non-farm Sector in Rural Development in Lesotho', Journal of Modern African Studies 54(2): 317-338. 
Rust, J.M. (2018) 'The Impact of Climate Change on Extensive and Intensive Livestock Production Systems', Animal Frontiers 9(1): 20-25.

Sarkar, A. (2020) 'Role of Livestock Farming in Meeting Livelihood Challenges of SC Cultivators in India', Indian Journal of Human Development 14.1 DOI: 10.1177/0973703020923863 (Accessed: 21 April 2021).

Slavchevska, V. (2015) 'Gender differences in agricultural productivity: the case of Tanzania', Agricultural Economics 46(3): 335-355.

Speranza, C.I. (2010) 'Drought Coping and Adaptation Strategies: Understanding Adaptations to Climate Change in Agro-pastoral Livestock Production in Makueni District, Kenya', European Journal of Development Research 22(5). Available at: DOl:10.1057/ejdr.2010.39 (Accessed: 23 April 2021).

Sumberg, J. (2003) 'Toward a Dis-aggregated View of Crop-livestock Integration in Western Africa', Land Use Policy 20: 253-264.

Thornton, P.K. and Herrero, M. (2015) 'Adapting to Climate Change in the Mixed Crop and Livestock Farming Systems in Sub-Saharan Africa', Nature Climate Change 5: 830-836.

Thornton, P.K., Jones, P.J., Ericksen, P.J. and Challinor, A.J. (2011) 'Agriculture and food systems in sub-Saharan Africa in a $4^{\circ} \mathrm{C}+$ world'. Philisophical Transactions and the Royal Society 369(1934). Available at: https://doi. org/10.1098/rsta.2010.0246 (Accessed: 15 April 2021).

Turaa, E.G., Goshub, D., Demisiec, T. and Kenead, T. (2016) 'Determinants of Market Participation and Intensity of Marketed Surplus of Teff Producers in Bacho and Dawo Districts of Oromia State, Ethiopia', Journal of Development and Agricultural Economics 5(2):020-032.

United Republic of Tanzania (URT) (2020). Kilimo Statistics. Available at: https://www.kilimo.go.tz/index. php/en/ resources/view/agriculture-basic-data-2005-2006-2009-2010 (Accessed: 22 April 2020).

Wallace, M.T. and Moss, J.E. (2002) 'Farmer Decision-Making with Conflicting Goals: A Recursive Strategic Programming Analysis', Journal of Agricultural Economics 53(1): 82-100.

Wanka, F.A. and Rena, R. (2019) 'The Impact of Educational Attainment on Household Poverty in South Africa: A Case Study of Limpopo Province', African Journal of Science, Technology, Innovation and Development 11(5): 597-609.

Wiggins, S., Argwings-Kodhek, G., Gebreselassie, S., Asuming-Brempong, S., Chirwa, E., Matita, M.M., Mdoe, N. and Mutabazi, K. (2014). Cautious Commercialization: Findings from Village Studies in Ethiopia, Ghana, Kenya, Malawi and Tanzania, FAC Working Paper 82, Brighton: Future Agricultures Consortium. Available at: https://assets.publishing.service.gov.uk/media/57a089aae5274a31e00001e6/FAC_Working_Paper_082.pdf (Accessed: 25 March 2021).

Wiggins, S., Argwings-Kodhek, G., Leavy, J. and Poulton, C. (2011) Small Farm Commercialization in Africa: Reviewing the Issues, FAC Research Paper 23, Brighton: Future Agricultures Consortium (Accessed: 25 March 2021).

Wooldridge, J.M. (2010) Econometric Analysis of Cross Section and Panel Data, Cambridge MA: MIT Press.

Zhou, S., Minde, I.J. and Mtigwe, B. (2013) 'Smallholder Agricultural Commercialization for Income Growth and Poverty Alleviation in Southern Africa: A Review', African Journal of Agricultural Research 8(22): 2599-2608. 


\section{ANNEXES}

Annex 1: Specification of explanatory variables used in the fractional probit model for determinants of crop commercialisation

\begin{tabular}{|c|c|c|}
\hline Variable & Description & $\begin{array}{l}\text { Expected } \\
\text { sign }\end{array}$ \\
\hline Sex of household head (dummy) & Sex category of household head: 1 if male, 0 if female & $+/-$ \\
\hline Age of farmer (dummy) & Age category of famer: 1 if young and 0 if old farmer & $+/-$ \\
\hline Education of household head & Year of schooling for household head & + \\
\hline Household size & Number of people in a household & $+/-$ \\
\hline Total crop land & Hectares (ha) of land planted with crops & + \\
\hline Livestock kept & Number of livestock kept in TLU & + \\
\hline Use of tractor & 1 if farmer uses tractor as tillage implement, 0 if hand hoe & + \\
\hline Use of animal traction & 1 if farmer uses animal traction as tillage implement, 0 if hand hoe & + \\
\hline Access to extension & 1 if farmer has access to extension services, 0 otherwise & + \\
\hline Use of purchased seed & 1 if farmer used purchased seed, 0 otherwise & + \\
\hline Use of inorganic fertiliser & 1 if farmer used of inorganic fertiliser, 0 otherwise & + \\
\hline Use of organic fertiliser & 1 if farmer used organic fertiliser, 0 otherwise & + \\
\hline Use of pesticide & 1 if farmer used pesticide, 0 otherwise & + \\
\hline Non-farm income & $\begin{array}{l}\text { Non-farm income earned by the household in Tanzanian shillings } \\
\text { (TSh) }\end{array}$ & - \\
\hline Distance to nearest motorable road & $\begin{array}{l}\text { Distance in kilometres from farm to motorable road as a proxy of } \\
\text { market access }\end{array}$ & - \\
\hline
\end{tabular}

Source: Authors' own 
Annex 2: Indicators used to compute Multi Poverty Index (MPI)

\begin{tabular}{|c|c|c|}
\hline $\mathrm{S} / \mathrm{N}$ & Indicator & Measurement \\
\hline 1 & Years of schooling & $\begin{array}{l}\text { Assigned } 1 \text { for a household that did not have any member who has at least five years of } \\
\text { schooling and } 0 \text { otherwise }\end{array}$ \\
\hline 2 & School attendance & Assigned 1 for a school-age child out of school, and 0 otherwise \\
\hline 3 & Child mortality & $\begin{array}{l}\text { Assigned } 1 \text { for a household that reported a death of a child in the household during the } \\
\text { past ten years, and } 0 \text { for a household that had not }\end{array}$ \\
\hline 4 & Nutrition & $\begin{array}{l}\text { Used the Food Insecurity Experience Scale with a cut-off point of five, where those } \\
\text { scoring five and above out of nine were considered to be deprived nutritionally (See list of } \\
\text { food insecurity situation in Annex } 2 \text { b below). }\end{array}$ \\
\hline 5 & Living standards: & \\
\hline i & Electricity & Assigned 1 for a household that did not have electricity, and 0 for one that had electricity \\
\hline ii & Drinking water & $\begin{array}{l}\text { Assigned } 1 \text { for a household that did not have access to clean water, i.e. use unprotected } \\
\text { sources, and } 0 \text { for a household that had access to clean drinking water. }\end{array}$ \\
\hline iii & Sanitation & $\begin{array}{l}\text { Assigned } 1 \text { for a household that did not have adequate sanitation (i.e. no toilet facility, go } \\
\text { to bush or field, use pan or bucket, use traditional pit latrine), and } 0 \text { for a household that } \\
\text { had a ventilated improved pit latrine and a flush toilet }\end{array}$ \\
\hline iv & Flooring & $\begin{array}{l}\text { Assigned } 1 \text { for a household that had dirty, earth, dung floor etc, and } 0 \text { to a household that } \\
\text { had a tiled, cemented, concrete floor. }\end{array}$ \\
\hline v & Cooking fuel & $\begin{array}{l}\text { Assigned } 1 \text { for a household that cooked with wood, charcoal or dung, and } 0 \text { was given to } \\
\text { a household that used gas, electricity or paraffin as the main source of cooking energy }\end{array}$ \\
\hline vi & Asset ownership & $\begin{array}{l}\text { Assigned } 1 \text { for a household that did not own did not own a car or tractor, or more than } \\
\text { one of the following: radio, TV, telephone, bicycle, motorcycle, or refrigerator; the value of } 0 \\
\text { was given to a household that owned more than one of the listed assets }\end{array}$ \\
\hline
\end{tabular}

Source: Authors' own

Annex 3: List of food insecurity situations used to classify households into food secure and food insecure households (HFSS)

\begin{tabular}{|c|c|}
\hline SN & Food Insecurity Situation \\
\hline 1 & Worries about not having enough food to eat because of a lack of money or other resources \\
\hline 2 & $\begin{array}{l}\text { Household members being unable to eat healthy and nutritious food because of a lack of money or other } \\
\text { resources }\end{array}$ \\
\hline 3 & Household members eating only a few kinds of foods because of a lack of money or other resources \\
\hline 4 & $\begin{array}{l}\text { Household members skipping a meal because there was not enough money or other resources to get } \\
\text { food }\end{array}$ \\
\hline 5 & $\begin{array}{l}\text { Household members eating less than they thought they should because of a lack of money or other } \\
\text { resources }\end{array}$ \\
\hline 6 & Household running out of food because of a lack of money or other resources \\
\hline 7 & $\begin{array}{l}\text { Household members being hungry but did not eat because there was not enough money or other } \\
\text { resources }\end{array}$ \\
\hline 8 & Household members going without eating for a whole day because of a lack of money or other resources \\
\hline 9 & Household head not having enough food to meet family's needs \\
\hline
\end{tabular}

Source: Authors' own 
Annex 4: List of explanatory variables for estimating the probit model for MPI

\begin{tabular}{|l|l|l|}
\hline Variable & Description & $\begin{array}{l}\text { Expected } \\
\text { sign }\end{array}$ \\
\hline Sex of household head (dummy) & Sex category of household head: 1 if male, 0 if female & + \\
\hline Age of farmer (dummy) & Age category of farmer: 1 if young and 0 if old farmer & +- \\
\hline Education of household head & Year of schooling for household head & + \\
\hline Household size & Number of people in a household & - \\
\hline Total crop land & Hectares (ha) of land planted with crops & + \\
\hline Livestock kept & Number of livestock kept in TLU & \\
\hline Non-farm income & $\begin{array}{l}\text { Non-farm income earned by the household in Tanzanian shillings } \\
\text { (TSh) }\end{array}$ & \\
\hline Level of crop commercialisation & $\begin{array}{l}\text { Modelled as commercialisation tercile dummies, with low } \\
\text { commercialisation tercile as reference category }\end{array}$ & - \\
\hline Second tercile (CC_T2) & 1 if second tercile and 0 otherwise & - \\
\hline Third tercile (CC T3) & 1 if third tercile and 0 otherwise & \\
\hline
\end{tabular}

Source: Authors' own 
Annex 5: Map of the Singida region and Iramba and Mkalama districts

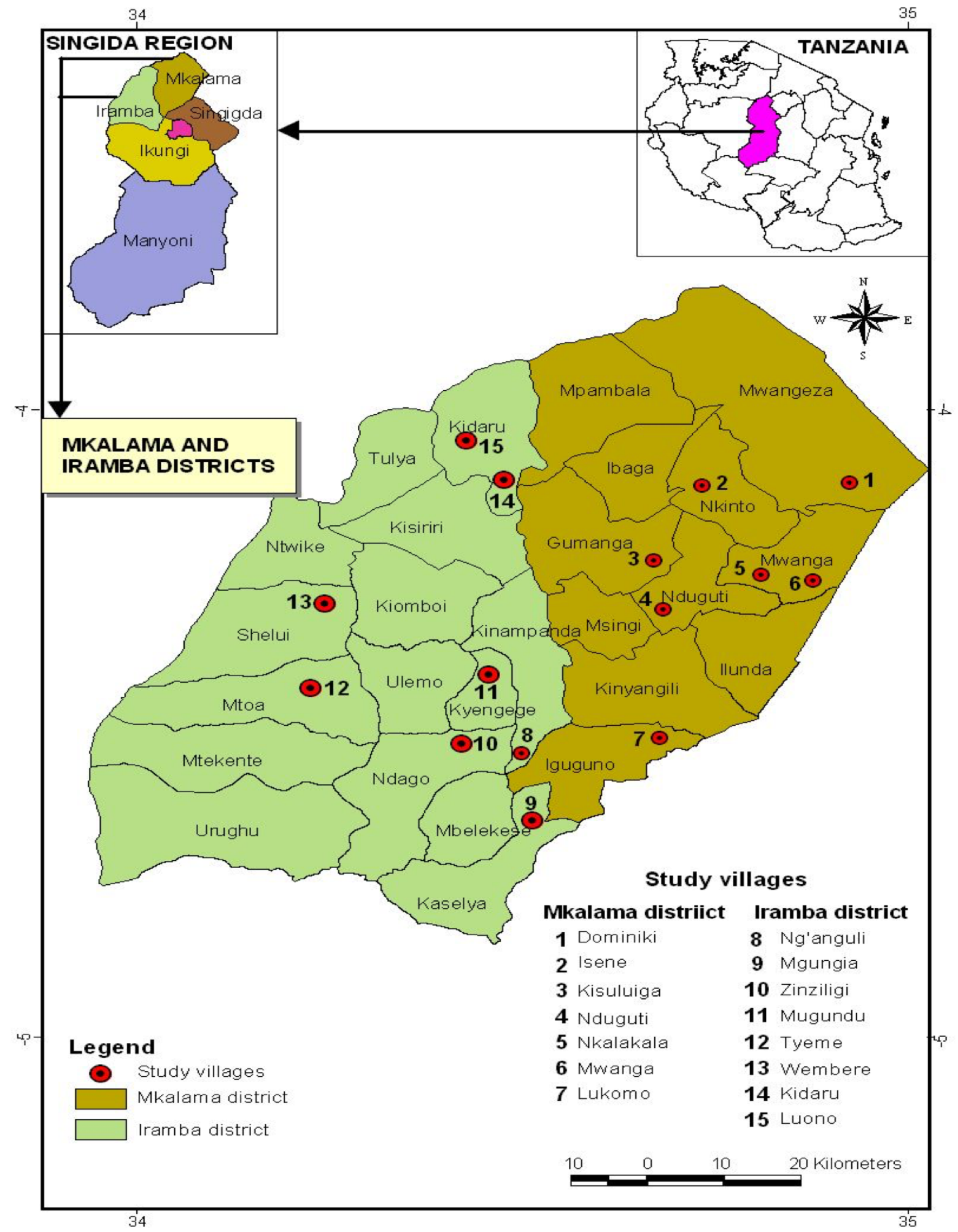

Source: Authors' own 
Mdoe, N.S.Y., Mlay, G.I., Boniface, G., Isinika, A.C. and Magomba, C. (2021) Livestock, Crop Commercialisation and Poverty Reduction Among Rural Households in the Singida Region, Tanzania, APRA Working Paper 65, Brighton: Future Agricultures Consortium

DOI: 10.19088/APRA.2021.024

\section{(cc) BY-NC-ND}

This is an Open Access report distributed under the terms of the Attribution-Non Commercial-No Derivs 4.0 Unported (CC BY-NC-ND 4.0) Attribution - You must give appropriate credit, provide a link to the license, and indicate if changes were made. You may do so in any reasonable manner, but not in any way that suggests the licensor endorses you or your use. NonCommercial — You may not use the material for commercial purposes. NoDerivatives - If you remix, transform, or build upon the material, you may not distribute the modified material. You are free to: Share - copy and redistribute the material in any medium or format.

https://creativecommons.org/licenses/by-nc-nd/4.0/legalcode

If you use the work, we ask that you reference the APRA website (www.future-agricultures.org/apra/) and send a copy of the work or a link to its use online to the following address for our archive: APRA, Future Agricultures Consortium, University of Sussex, Brighton BN1 9RE, UK (apra@ids.ac.uk)

All APRA Working Papers go through a review process before publication.

\section{Cc) creative}

\section{DO YOU HAVE COMMENTS ON THIS PAPER?}

We would welcome your feedback on this working paper!

To provide brief comments, please follow this link to our short APRA Working Paper Feedback form: https://goo.gl/forms/1iVnXhhrlGesfR9

Agricultural Policy Research in Africa (APRA) is a programme of the Future Agricultures Consortium (FAC) which is

generating new evidence and policy-relevant insights on more inclusive pathways to agricultural commercialisation in sub-Saharan Africa. APRA is funded with UK aid from the UK Foreign, Commonwealth \&

Development Office (FCDO) and will run from 2016-2022.

The APRA Directorate is based at the Institute of Development Studies (IDS), UK (www.ids.ac.uk), with regional hubs at the Centre for African Bio-Entrepreneurship (CABE), Kenya, the Institute for Poverty, Land and Agrarian Studies (PLAAS), South Africa, and the University of Ghana, Legon. It builds on more than a decade of research and policy engagement work by the Future Agricultures Consortium (www.future-agricultures.org) and involves more than 100 researchers and communications professionals in Africa, UK, Sweden and USA. 